\author{
Madhav Manohar \\ Professor and Head, CIv1I EngIneering Department \\ Birla Institute of Technology \\ Ranch1, Ind1a.
}

\title{
INTRODUCTION
}

The movement of sedimentary matter along the coastal regions of the land has always been a problem in coastal and harbour engineering. Erosion and accretion of the shore and the sea bottom and the silt charge from the rivers discharging into the sea contribute the necessary sediment that moves along the coast.

Coastal sediment movement is mainly due to the action of the waves (Eaton, 1950; Johnson, 1919). The var1ability of the wave energy and the resistance of the sediment against transportation govern the attainment of the equilibrium profile of the shore, a condition that is only transitory. Coastal and bottom erosion and accretion are two processes which are continuous throughout all the seasons.

Though much of the sediment that moves along the coast is obtained from the surf zone, a small part of 1 t is also derlved from the shallow water and deep water zones because of the gradual shifting of the sediment at the ocean bottom especiaily in the shaliow water zone, where the oscillatory waves from deep water transform to solitary waves (Dally and stephen, 1951) resulting in the existence of a differential in the velocity (Munk, 1944) of the forward and backward motions of water at the bottom.

Even in deep water there is evidence of sediment movenent. According to Kuenen (1950), off Land's End in Cornwall In Great Britain, stones upto one $1 \mathrm{~b}$. In weight are moved at jepths of 180 '. In general, however, only very fine sediment is moved at such great depths. on reaching the surf zone, it is transported along the coast as littoral drift.

On the basis of laboratory studies (Manohar, 1955) it nay be concluded that all motions of sediment beyond the surf cone occur within a boundary layer created at the bottom due ;o the effects of viscosity of water. Very fine sediment (Iess than $0.3 \mathrm{~mm}$. In diameter) move in a laminar boundary layer with the movement caused by laminar shear while larger sediment move due to turbulence and lift forces in a turbulent soundary layer. Figures $1,2,3$ and 4 are based on that itudy and with those nomographs and with the knowledge of the sediment sizes, depths under consideration and wave characieristics such as wave length, halght and period, it will be 
possible to obtain an approximate estimation of sediment mov ment beyond the surf zone. Normally the sediment movement the bottom beyond the surf zone, may be in the form of rolld sliding and saltation, while under stormy conditions, it maj be in the form of suspension close to the bed. F1g. 4 may used to determine the limits of sediment motion in suspensic

Considering the surf zone which is the chief source c sediment moving along the coast, strong local churning up of sand due to the turbulent action of the waves occurs as the waves break in that zone at depth approximately equal to 1 helght of the waves. At the so called plung point, four $t c$ five times as much sediment is ralsed as in the Immediate neighbourhood. The movement of this sediment along the coast from the point from where it is disturbed depends to : large extent on what is called 'nearshore circulation' (She. pard and Inman, 1950). Observations of nearshore circulation show that there are two inter-related current systems prevalent along the coast. The first type designated as $t$ l coastal currents is induced due to the tides, or and winds. In general, they flow roughly parallel to the coast and con. sist of a relatively uniform drift in waters adjacent to thi surf zone.

The second type which is far more important with reference to the sediment motion along the coast is the inear. shore system'. It is mainly due to wave action and occurs in and noar the breaker zone. When waves travel shoreward there is a large transport of water shoreward rushing ob11quely up the coast. This mass or water is known as swas This obliqueness in the travel and breaking of the waves ge: rate an alongshore component in the wave energy resulting 1 the movement of water parallel to the coast known as alongshore or 11ttoral current (Johnson, 1953, 1956, 1957). Whe: the swash dies away, the water that has not percolated down returns directly seaward. The seaward return flow may als generate $r i p$ currents which also move in the direction of the alongshore current. The nearshore system, therefore, consists of swash, rip currents and the alongshore currents In general, the swash provides the sediment in suspension, the longshore currents move it in the direction of the $1 r$ tr vel and part of $1 t$ returns back seaward. The seaward move ment is, rather, very small and as such most of the sedimen churned up by wave action travels in the direction of the longshore current.

According to W.V.Lewis (Kuenen, 1950) there are two different types of waves that break on the shore and contri bute to the sediment motion along the coast. They are (1) destructive waves and (2) constructive waves. The destruc tive waves are Irregular, steep, close together, have a marked orbital motion and break and plung down vertically. The power of the backwash is more than that of the swash which though large in volume mixes with the backwash of the 


\section{SEDIMENT MOVEMENT AT SOUTH INDIAN PORTS}

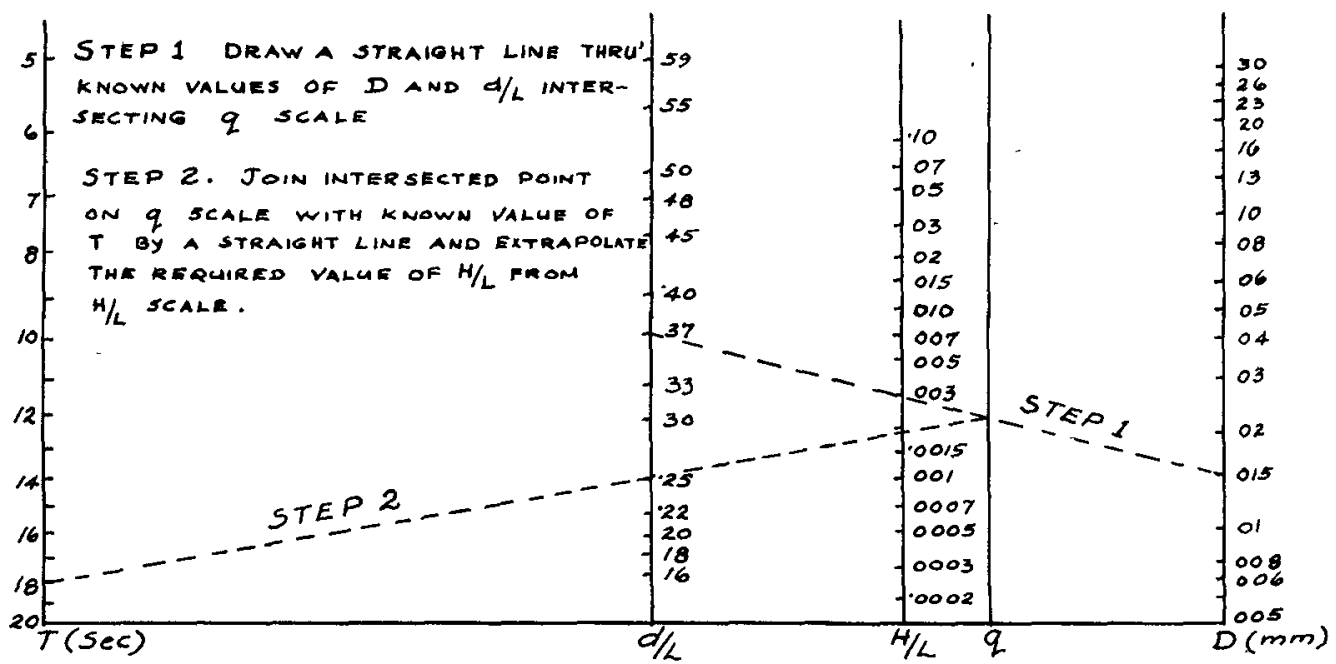

Fig. 1. Nomograph: Bottom sediment movement due to wave action in laminar boundary layer.

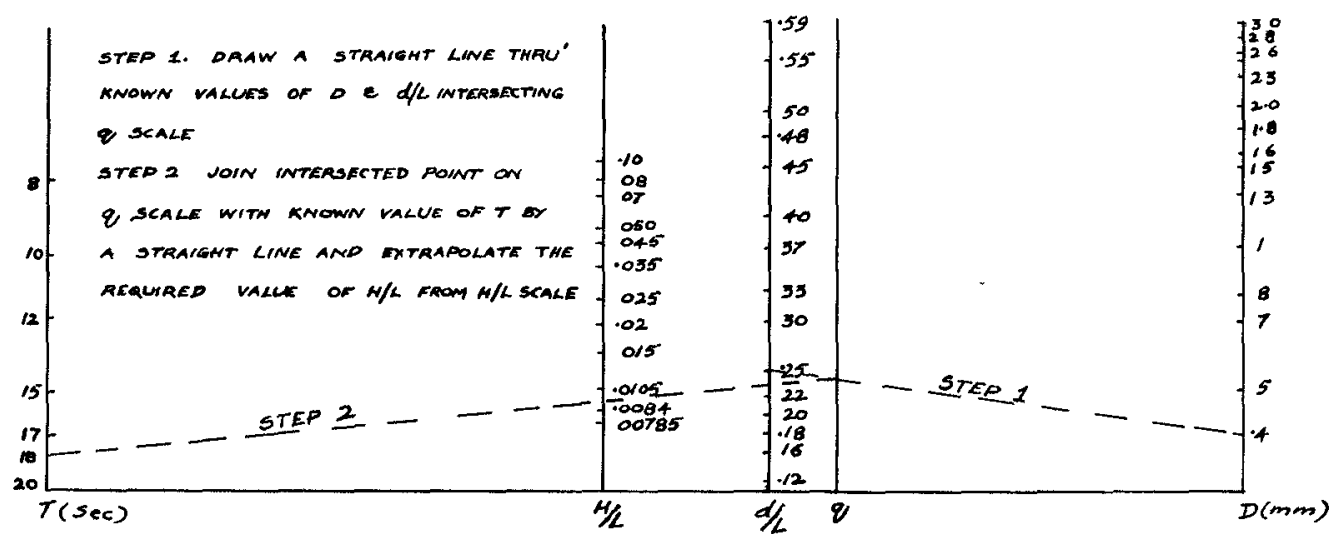

Fig. 2. Nomograph: Bottom sediment movement due to wave action in turbulent boundary layer.

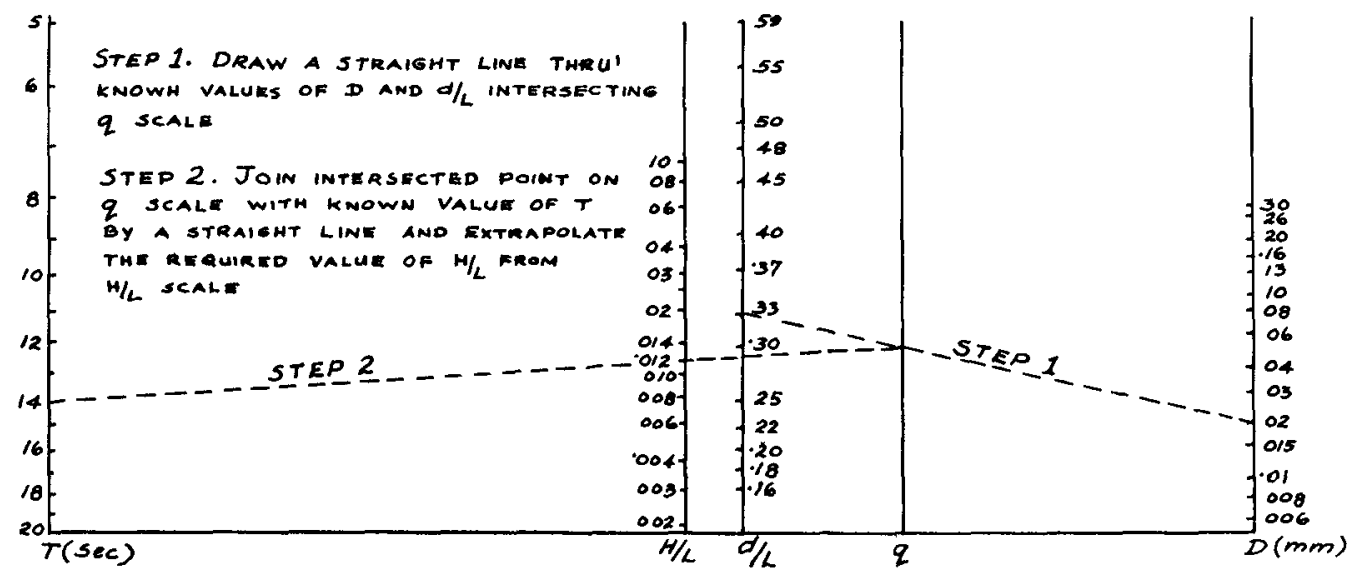

Fig. 3. Nomograph: Bottom sediment ripple formation due to wave action . 
preceding wave and spreads weakly over the beach. Strong a shore winds generate this type of wave and in this, the back. wash which is fairly large induces erosion of the beach and churning up of the sediment within the surf zone. On the other hand, constructive waves are 10ng, have a regular elliptical orbital motion and break more regularly. They break less vertically and move obliquely forward. More energy is transmitted forward to the swash which though less in volume is more powerful and effective. The beckwash is weaker since the swash spreads over a larger area and is ios. by percolation. Thus the sediment brought up by the swash Is slowly added to the beach and to the alongshore movement. These waves are generated by far off winds. It is possible that a wave may act as a destructive wave or a constructive wave depending upon the nature of the wave, and profile and composition of the beach. Destruct1ve waves may begin to work on a bech profile built up by constructive waves and vice versa. The breakers are also classifled as (1) plung Ing (2) spllling and (3) surging waves. Usually construct1ve waves are assumed to be of the spilling type and destructive waves of the plunging type. All the se types of breakers agitate the sediment within the surf zone and the sediment so agitated moves along the coast due to the alongshore component of wave energy.

\section{COASTAL CURRENTS}

The efrect of coastal currents on sediment motion is negligible. In deep water areas, the velocity of the currents at surface seldom exceeds $3 \mathrm{ft}$. per sec. while in shallow water, it may silghtiy exceed that value. Similarl wind driven currents under favourable circumstances may also attain that magnitude of velocity. In general, the average velocity varies logarithmically (Kuenen, 1950) with helght above the bottom with the result that the bottom velocities seldom exceed a few inches per second. These velocities ar too small to move the coarse sediment. The se may cause movement of the fine sediment which is always in suspension but this type of sediment does not affect the configuration of the shoreline.

\section{IITTORAL CURRENT, DRIFT AND TRANSPORT}

As is already known (Eaton, 1950; G1lbert, 1890 ; John son, 1953, 1956, 1957) 11ttoral currents are mainiy respons1 ble for the alongshore movement (11ttoral transport) of the sediment (11ttoral drift). These currents may act in the same direction as the coastal currents or they may act in the opposite direction. In both cases, the ir magnitude is far in excess of the coastal currents with the result that the littoral material moves in their direction. Though the general littoral drift may be in one direction during a particular season or per1od, a local drift in the reverse direction is also possible. For example at Chichester alon the cosst of Great Britain, the main littoral arift is from 


\section{SEDIMENT MOVEMENT AT SOUTH INDIAN PORTS}

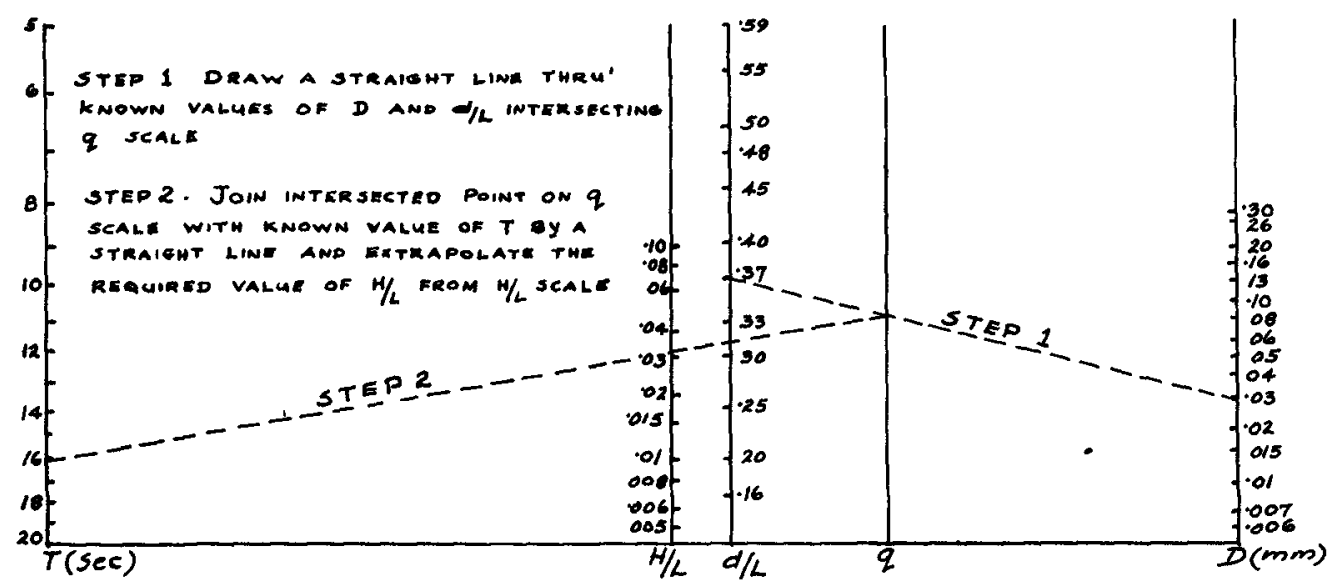

Fig. 4. Nomograph: Bottom sediment in suspension due to wave action.

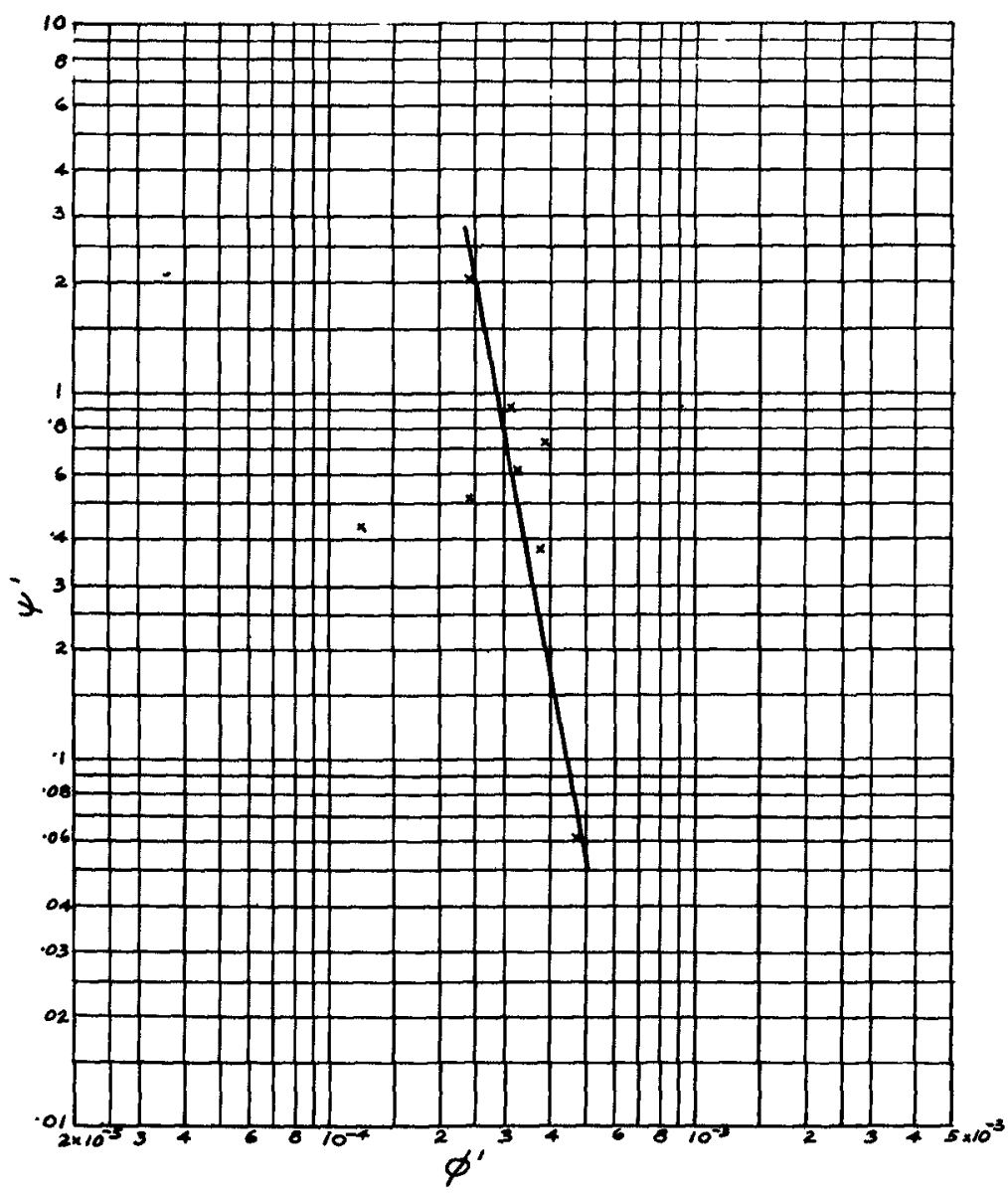

No. 5. Littoral transport functions . 
west to east whlle at the Chichester harbour 1tself, it is from east to west.

The general direction of littoral drift can be determined (U.S.Army, 1954) from the development of accretion and erosion near manmade structures such as jettles, groins and breakwaters, natural barrlers such as headlands, sandspits and underwater bars, examination of beach and bed materials, current measurements and by refraction analysis (Dunham, 195C Johnson, 1953) of wave energy at the coast in consideration. The last method loses its accuracy in zones of Irregular tor graphy.

Rate of Littoral Iransport - The amount of sediment movement that 1s, the rate of 11ttoral transport is a function of the wave characteristies, the sediment and the configuration of the shoreline. Depending upon the rate of supply and rate of transport of sediment, there can be elther accretion or erosion or an equilibrium state. The only rellable method that is arailable at present to determine the rate of litto ral transport consists in trapping and measuring the littor: drift at a natural or artificlal barrier. A general relationship involving the rate of transport, wave and sediment character1stics has yet to be evolved though Caldwell (1956 was able to obtain a valuable relationship between alongsho wave energy and concurrent rate of littoral transport from his studies of sand movement near Anaheim Bay in Callfornia and near South Lake Worth Inlet in F1orida (Watts, 1953).

It seems to the author that the analysis of 11ttoral transport can also be based on the concept of probab1lity similar to the theory as evolved by Einstein (1942, 1950) for unidirectional flow. Einstein in his theory of bed 10 transport in uni-directional flow, introduced two dimension less functions, namely the $\phi$ function representing intensity of bed load transport and the $\psi$ function reprem senting the intensity of flow at the sediment level and for that the se were universally related. As a further proof that EInste in's theory was besed on a correct approach to sediment transport mechan1sm, Tsubak1, Kawasum1 and Yasuton (1953) found that Binste in's $\%$ function governed the dime sions of the ripples generated in un1-directional flow.

The author (1955) based his theory on bottom sedimel motion due to wave action on an analysis similar to EInstein's approach and found that a dimensionless function representing intensity of flow over the sediment could be used to represent every bottom sediment motion in turbulen flow Including development and disappearance of ripples. Though the flow at the bottom was osc1llatory, the maximum instantaneous velocity of flow during its motion was taken to derlve the dimensionless function $\psi_{1}$. The author b lieves that a sinliar approach can be adopted to determine the rate of littoral transport. 
When the waves break, they throw part of the sediment (finer) into suspension. The rest is in motion in the form of rolling, sliding, skips and hops. Thus the sediment in motion due to turbulence and lift forces is carried along the shore by the longshore current. The longshore current though not always strong enough to dislodge the sediment at rest acts as the transporting agent. Since the sediment and the wave characteristics govern the rate of 11ttoral transport and since the longshore current is a function of the wave characteristics and the beach profile, it can be used along with the sediment characterist1cs to determine the rate of i1ttoral transport. With this assumption many of the variables involved can be represented by a single variable namely the longshore current. On this basis and Einstein's theory of sediment transport, the author conducted a preliminary study of littoral transport from the date obtalned from Anaheim Bay, (Caldwell, 1956) California. Einstein's $\phi$ function, namely,

$$
\phi^{\prime}=\frac{q_{a}}{\rho_{s} g}\left(\frac{\rho_{f}}{p_{s}-p_{f}}\right)^{1 / 2}\left(\frac{1}{g D^{3}}\right)^{1 / 2}
$$

was retained as such while the $\psi$ function was taken in the form of

$$
\psi^{\prime} \approx \frac{W^{\prime}}{L} \approx \frac{g\left(\rho_{s}-\rho_{f}\right) A_{2} D^{3}}{C_{L} \rho_{f} V_{2}^{2} A_{1} D^{2}}
$$

where $v=$ longshore velocity obtained from wave characteristics and $D=$ representative sediment diameter. The $\phi^{\prime}$ and $\psi$ ' functions were found to be governed by a definite relationship (F16.5) indicating a probable approach to the determination of rate of littoral transport. However, it should be noted that the results thus obtained are based on very meagre data.

The value of the longshore current $v$, that is Included in the expression $\psi^{\prime}$, may be obtalned from the following Pormulae and nomograph' (F1g. 6) (Inman, Quinn, 1951). The equation may be written in the following form

$$
\begin{aligned}
V & =\frac{a}{2}\left[\sqrt{\left.1+\frac{4 c \sin \alpha}{a}-1\right]}\right. \\
& a=(2.61 \mathrm{Hi} \cos \alpha) \div k T \\
c & =\sqrt{2.28 g H} \\
k & =0.024 \mathrm{~V}^{-15}
\end{aligned}
$$

In the nomograph or alignment chart, the longshore current $v$, in $\mathrm{ft} . / \mathrm{sec}$ can be readily obtalned when wave breaker helght in $\mathrm{ft}$., wave period in sec, beach slope in percent and angle of wave breaker approach in degrees are known. Though this approach is rather an approximation with uniform conditions assumed, the author belleves that $1 t$ should prove helpful in the determination of rate of littoral transport. 
Effect on Littoral Barriers - As is woll known, the movement of sediment towards and along the shore has an important bearing on the location of man-made structures and harbour sites. On the updrift side of the barrier, sediment will accumulate causing accretion and on the down drift side, deilclency in sediment supply will result in erosion. In both cases, the shore-lime will tend towards re-alignment to an equilibrium profile in a direction normal to the rem sultant of the ilttoral forces which may roughly be estimater by drawing normals to orthogonals in a refraction diagram prepared for the zone under consideration. Harbour protec$t$ ion works such as break-waters and jettles and navigat lonal works such as dredged channels should be aligned in such a way that they interfere as little as possible with the natural littoral transport and yet protect the harbour and the navigational channel against fililing. If this is not possible, then prevent Ive measures should be taken to prevent starvation of the down drift shore, excessive accretion of the updrift shore and keep the channel and the harbour from being put out of action. Depending upon the type of littow ral barrier, the amount of littoral drift, the wind and the wave system, and the orlentation of the coast, the types of protective works will vary considerably.

Types of Harbour Sites - Harbours in South India with refem rence to their location along the coast, may be classified differently and so it may be worthwhile to mention the different types of harbour sites and their sedimentation problems. Depending upon their location, harbours can be classifled as river channel harbours, off-river harbours, fallIIne harbours, tidal channel harbours, off-channel harbours and shore-ilne harbours (Caldwell 1950), (Mason, 1950).

River channel harbours bullt along the river-side wit sufficient depth for navigation can be maintained without ox cessive maintenance work. The effect of coastal sediment movement on the harbour itself is very slight. However, th formation of shoals and bars at the mouth of the river, thel frequent changes depending upon the amount of sediment brought down by the rivers, the interception of the longshore current and therefore the i1ttoral transport by the higher velocity of discharge from the river and the consequent settilng of the coastal sediment in adjacent areas an the silting of the navigational channel due to the above causes are some of the problems involved in the upkeep of such harbour sites. In the dredged channel, since the dept is greater than normal, the waves do not break and the botto velocity is insufficient to transport material across the channel and thus the material deposits in the dredged portions. But in the case of river channel harbours, this problem is not of great magnitude since nature itself provides a channel for the discharge of river flow into the sea The maintenance of such a channel will be comparatively easy This, however, disturbs the material balance on the down- 


\begin{tabular}{|c|c|c|c|c|c|c|c|c|c|c|c|c|c|c|c|c|}
\hline $\begin{array}{l}\frac{\nu}{\alpha} \\
\frac{\alpha}{\alpha} \\
\frac{\Sigma}{\alpha} \\
\alpha\end{array}$ & & 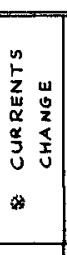 & 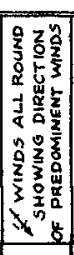 & \begin{tabular}{|l|}
$a$ \\
$a$ \\
$a$ \\
\end{tabular} & $\begin{array}{l}\tilde{a} \\
\ddot{a} \\
x\end{array}$ & & & & & 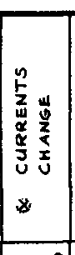 & 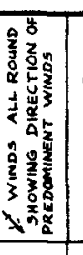 & $\begin{array}{l}a \\
\ddot{A} \\
\vdots\end{array}$ & & & & \\
\hline 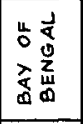 & $\checkmark$ & - & 1 & 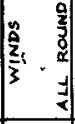 & $x$ & 1 & 1 & 1 & 1 & & $\searrow$ & $\lambda$ & 4) & n & $n$ & 次 \\
\hline 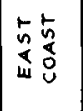 & $t$ & $t$ & $f$ & $t$ & $\star$ & t. & + & + & + & 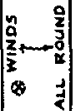 & 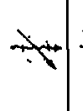 & + & $\checkmark$ & n & $\sim$ & 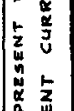 \\
\hline $\begin{array}{l}5 \\
\frac{5}{5} \\
3 \\
3\end{array}$ & $>$ & $x^{-\infty}$ & $\not A$ & 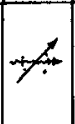 & $f$ & + & $\neq$ & $\not 2$ & $A F$ & $\not 4$ & 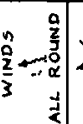 & $\neq$ & N & $a$ & + & 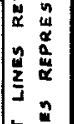 \\
\hline 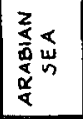 & $\gamma$ & 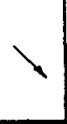 & 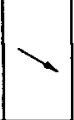 & 9 & 7 & $\backslash$ & 1 & 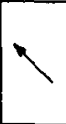 & 1 & $\rightarrow$ & $\Delta$ & 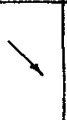 & $\bullet$ & . & + & 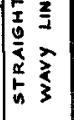 \\
\hline & 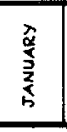 & 䇋 & 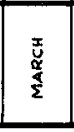 & 竞 & $\frac{\hat{x}}{2}$ & 嶧 & $\begin{array}{l}\hat{y} \\
\hat{n}\end{array}$ & 先 & 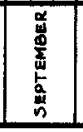 & 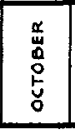 & 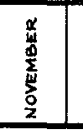 & 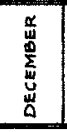 & $\begin{array}{l}z \\
w \\
w \\
z \\
z\end{array}$ & \begin{tabular}{|l|}
5 \\
5 \\
0 \\
0 \\
$z$ \\
2 \\
\end{tabular} & 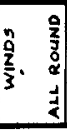 & 11 \\
\hline
\end{tabular}
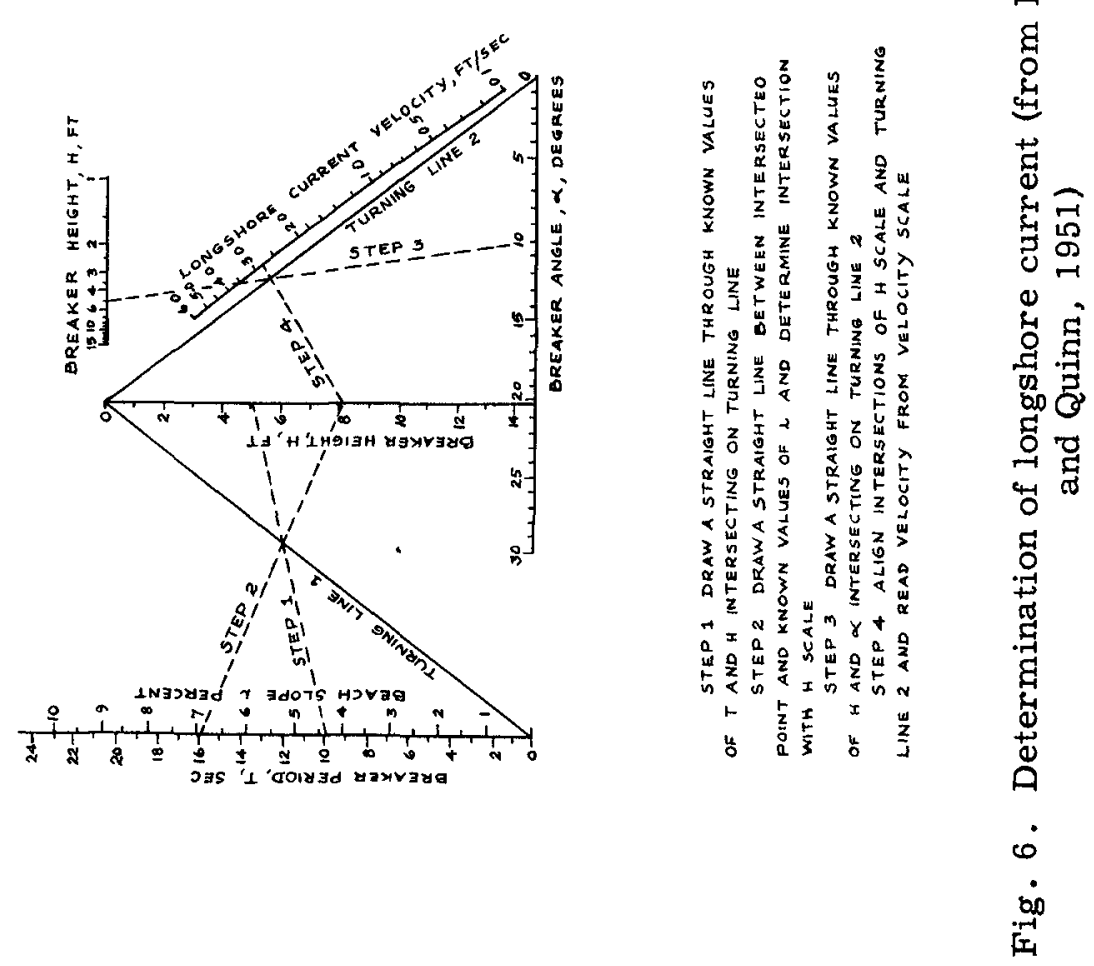
drift side and erosion takes place in that zone.

As the name 1tself suggests, an off-river harbour is a stagnant water pool situated away from the river channel proper and connected to the river channel by a navigation ac. cess channel. Coastal sediment elther from the sea or from the shoreline has little effect on these harbours except in the dredged navigation channel. Another trouble likely to occur with such harbours is the intermixing and the resultin flocculation and deposition of suspended material when silt and clay brought by fresh water from the river intermixes with salt water from the sea.

Tidal estuaries or bights which exist between turbulent mountain rivers and the sea sometimes offer as excellent sites for harbours. Such harbours are called fall-11n harbours. In such harbours, the effects of sediment from the coast and the sea are very small except during flood timi when some sediment w111 be carried to the harbour and into the navigational channel. The major trouble in such harbours is from the silt brought down by the river forming shoals and bars within the harbour area. V1zagapatam harbour on the east coast of South India about which reference w1Il be made later may be classifled as a fall-line harbour.

When harbours are located on tidal estuaries includin tidal rivers, bays and lagoons, they may be termed as 'Channel harbours in tidal estuaries'. The effect of sediment from coasts and sea on the se harbours is much more than in fall-line harbours due to great variations in tides and intermediate slack water periods. The sediment brought into the harbour area during the flood tides tends to deposit at the bottom during the slack water periods. Usualiy, when tidal estuaries are fod by rivers, this problem is of minor importance as compared to the formation of shoals due to the sand, silt and clay brought by the rivers as in the case of Mangalore port on the west coast of India. However, where t1dal bays exist, with no major river discharging into them, sediment transport from the sea during the flood tides becomes the chief source of trouble. Upkeep of dredged navigational channels connecting the sea and the har bour provides problems similar to those mentioned earlier. In some instances, excessive flocculation of silt and clay may result in the formation of mud-banks or mud-lumps along the coast at or near the mouths of rivers discharging into the sea. Cochin on the west coast of Ind1a is an example of this type of harbour. Where excessive shoaling exists 1 such harbours, the harbours may be located away from the mal channel in the tidal estuary. In such harbours, the effect of coastal sediment will be the same as in the previous case

When estuaries, rivers and other natural facilities do not exist for the location of a harbour, shoreline harbours are constructed directly on the open shore of oceans, 
bays or large lakes. Manmmade structures such as breakwaters and jetties or natural barrlers such as headlands prom jecting into the sea afford protection from waves within the harbour area. Such harbours always encounter excessive sedimentation from coastal material especially from littoral drift. These man-made structures arrest the movement of littoral drift, disturb equilibrium conditions along the coast, resulting in accretion on the updrift side and erom sion on the downdrift side. In course of time, the accre. tIon will gradually extend to the harbour entrance. It will then deposit in the lee of the breakwater depending upon the diffraction of the waves, (Johnson, 1951), and the magnitude of the velocities existing in that locality. The sediment that moves across the harbour entrance will deposit in the navigational channel causing further maintenance problems. In general, such harbours are constantly troubled by coastal sediment deposition and erosion depending upon the magnitude of littoral transport. Madras harbour on the east coast of India is an ideal example of a shore-ilne harbour.

With such a general analysis of coastal and botton sediment motion, an attempt is made below to describe the conditions as they exist along the coast of South India with particular reference to four harbours namely cochin and Mangalore on the wost coast and Madras and Vizagapatam on the east coast.

\section{WIND SYSTEM ALONG SOUTH INDIAN COAST}

Sediment movement at the shore and under water is due to the action of kinetic energy on the sediment. This kinetic energy is obtained from the wind, either directiy or through water waves resulting from the transfer of energy by the wind to the water-surface. Though waves may also, be generated by other sources of energy, such as earthmquakes, the principal cause is the action of wind on the water surface. In the Indian ocean, the outstanding feature of the wind system is the seasonal reversal of its direction known as the "monsoons" (Ind1a Meteorological Dept., 1941). The winds blow from a north-easterly direction during the North East Monsoon season from December to March, in which period, they are the strongest in January. From June to September, their direction is reversed and they move southwesterly and are called South West Monsoon winds. These are strongest in July. In general, the South West monsoon winds are stronger than those of the North East monsoon and as such they are the major cause of the littoral drift along the coast of India. Between these two main monsoons, there are two transition seasons so that there are altogether four seasons in a year and they may be described as follows:

a) N.E. monsoon season from December to March; 
b) Hot weather period from April to May just before the S.W. Monsoons.

c) S.W. monsoon season from June to September.

d) Transition monsoon period from october to November when south westerly winds are rem placed by northerly winds.

However, due to the rotation of the earth and other disturbing Influences such as the mountain ranges that ilo along the east and west coasts of India, the period, true d: rection and force of these wind systems are different on bol coasts and also at different places on each coast (Meteorol gical office, 1940).

Wind System on West Cosst - A generel idea of the wind syst, along the west coast may be obtained from Fig. 7 and the fo: lowing table.I.

The dally variation in morning land breeze and event: sea breeze due to the heating and cooling of the land is a marked feature of the coastal winds along the coast of Indi. except during the S.W. monsoon period when the skies are generally cloudy. Since the waves that reach the coast ar generated in the centre of the Arablan Sea, these local win do not greatly affect the direction of wave approach except during the transition monsoon period and the beginning of $t$ N.E. monsoon. The land breeze is strong from November to Pebruary though afternoon sea breeze is a regular feature throughout the season. From October to May, the winds are WNW during daytime and NE or BNE during the night. From October to January, the waves also approach the southern cosst from WW, WW or westerly direction. The maximum for of this wind system does not exceed a Beaufort scale of 2 . During the S.W. monsoon period from May to September when land breeze is absent, the waves approach the southern coas from about WSW or SW with the monsoon wind blowing from W $C$ WSW. From February to May, the wave direction at the coas is varlable but generally from WSW or Wespecially during $t$ latter part of the period.

\section{COCHIN HARBOUR}

Coasti1ne - The port of Coch1n (Bristow, 1930) is situated the west coast of Southern India (F1g. 4). From Cape Comc rin, the southernmost tip of India to Latitude $20^{\circ} \mathrm{N}$, the west coast consists of a coastline of 800 nautical miles. Running roughly parallel to the coastiline at a distance of about 20 to 50 miles inland, lies a continuous chain of mol tains, known as the Western Ghats, occasionally arising up1 an elevation of 8000 feet. Most of the rivers though the rise from the Western Ghats run towards the east coast and discharge into the Bay of Bengal (FIg, 8). Only small mol 


\section{SEDIMENT MOVEMENT AT SOUTH INDIAN PORTS}

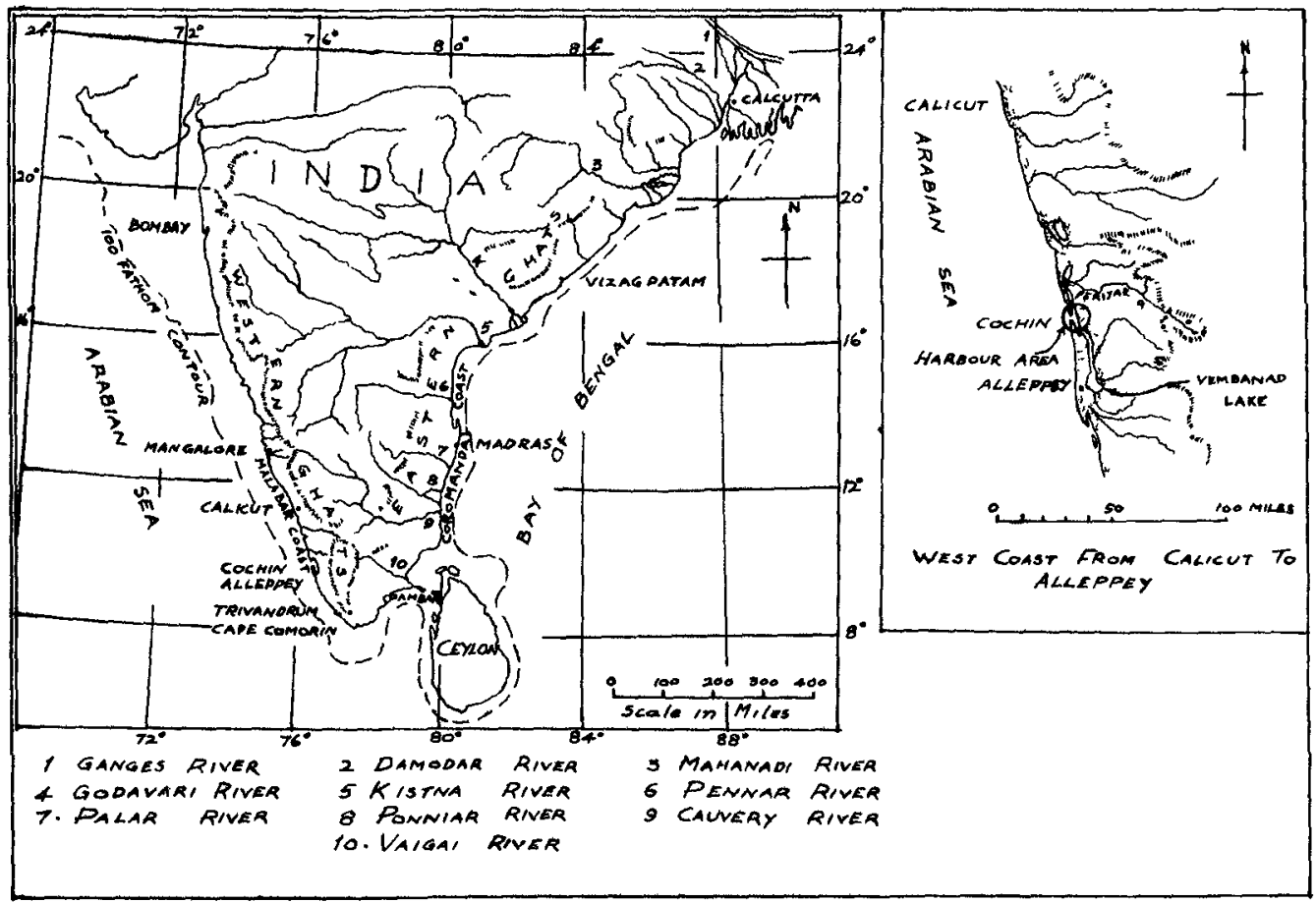

Fig. 8. Map of India with rivers and mountains.

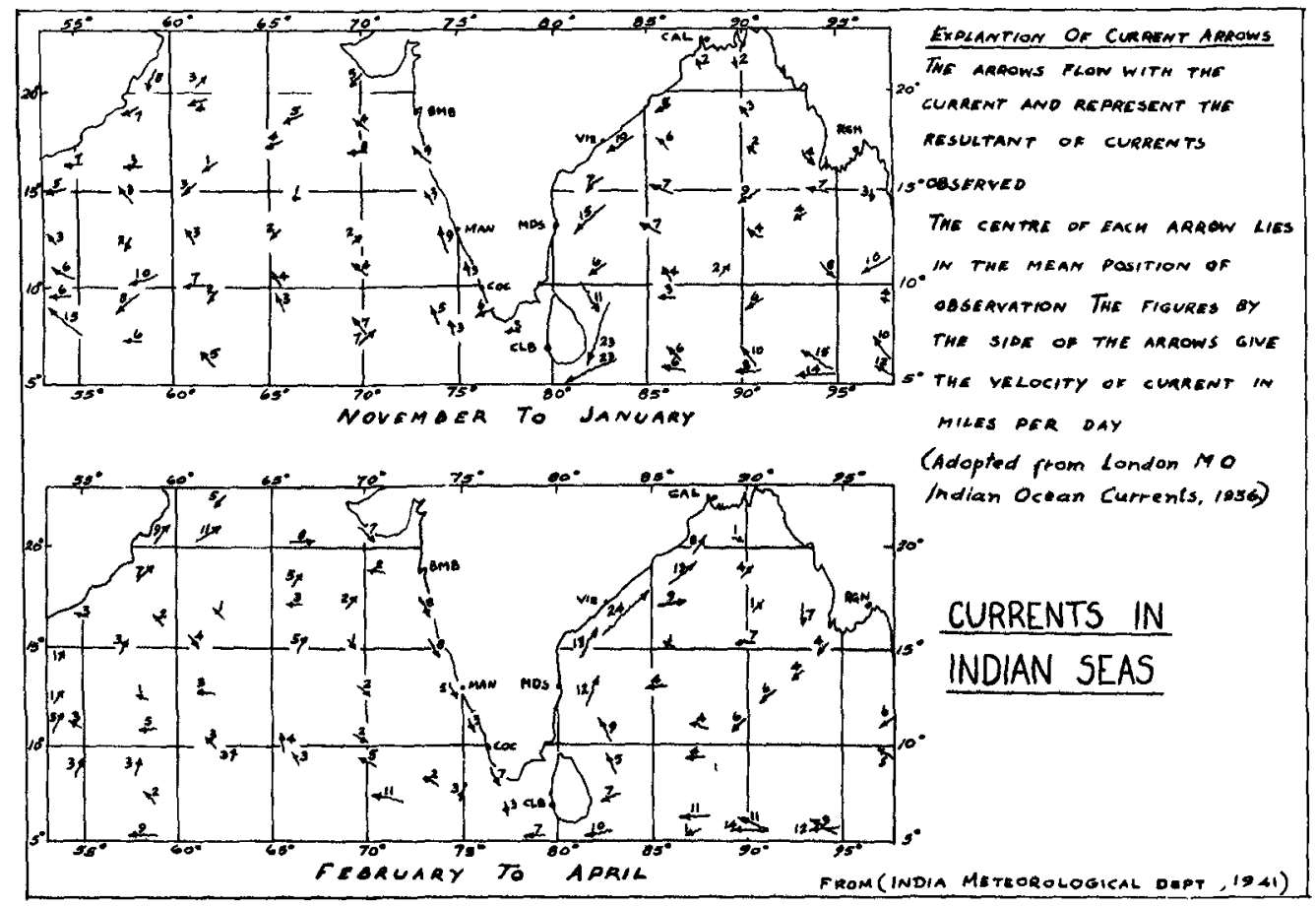

Fig. 9. Currents in Indian Seas - November to April. 
Table 1 .

\begin{tabular}{|c|c|c|c|c|}
\hline Month & $\begin{array}{c}\text { Wind } \\
\text { alrection }\end{array}$ & $\begin{array}{l}\text { Wind } \\
\text { force, } \\
\text { Beaufort } \\
\text { scale. }\end{array}$ & $\begin{array}{l}\text { Wind direc- } \\
\text { tion over } \\
\text { centre of } \\
\text { Arablan Sea }\end{array}$ & Remarks \\
\hline January & $\mathbf{N}$ & $2-3$ & NNE, NE & \\
\hline February & $\mathrm{N}, \mathrm{NNW}$ & $2-3$ & $N, N N E$ & $\begin{array}{l}\text { Frequent } \\
\text { Squalls with } \\
\text { a force of } 7\end{array}$ \\
\hline March & NNW & $2-3$ & $\mathrm{~N}, \mathrm{NNE}$ & \\
\hline Apr11 & $\mathbf{N} \mathbf{W}$ & $2-3$ & NNW, NNE & \\
\hline May & $\mathrm{NW}, \mathrm{W}$ & 3 & $\mathrm{NWW}$, to SW & $\begin{array}{l}\text { Frequent } \\
\text { Squalls of } \\
\text { force } 7\end{array}$ \\
\hline June & W, WSW & $4-5$ & W, WSW & $\begin{array}{l}\text { Wind force } \\
\text { upto } 8 \text { in the } \\
\text { centre of the } \\
\text { sea. }\end{array}$ \\
\hline July & $W, S W$ & $4-6$ & SW & $\begin{array}{l}\text { Wind force upt } \\
8 \text { in the centl } \\
\text { of the sea }\end{array}$ \\
\hline August & W, WSW & $4-6$ & SW & $\begin{array}{l}\text { Wind force up } \\
8-10 \text { in the } \\
\text { centre of the } \\
\text { sea }\end{array}$ \\
\hline September & NW & $3-4$ & $w, S w$ & $\begin{array}{l}\text { Wind force up } \\
7 \text { in the cent } \\
\text { of the sea }\end{array}$ \\
\hline October & $\mathrm{NW}$ & $2-4$ & NW to NE & \\
\hline November & $\mathbf{N}$ & $2-4$ & $\mathrm{NE}$ & \\
\hline December & $\mathrm{N}, \mathrm{NNE}$ & $2-3$ & $\mathrm{NE}$ & $\begin{array}{l}\text { Frequent gale } \\
\text { of force } 7\end{array}$ \\
\hline
\end{tabular}


tain streams, few in number, discharge into the Arablan Sea and though the sediment brought by these rivers forms bars at their mouths, generally they bring only comparatively smaller quantity of sediment than that discharged by rivers on the east coast. On the west coast of Southern Indla, a strip of laterite lies outside the granitoid gneiss formation of the Western Ghats and extends roughly from 4 to 6 miles from the coast, thus indicating that the recent deposits are only a few miles wide as compared to the many miles on the eastern side. This itself is an indication of the small quantity of ilttoral movement along the west coast of India. For a distance of 170 miles from Calicut to Cape Comorin this stretch of recent deposit, between the laterite strip and the coast, is mainly of alluvium.

Continental shelf - The continental shelf on the west coast of India extends outwards to an average depth of 100 fathoms. It is very wide in the north extending $120 \mathrm{mlles}$ seaward from the coast at latitude $20 \% \mathrm{~N}$. It narrows towards the south and is only 30 miles wide at Cape Comorin. However, just to the north of cochin and south of Quilon, there is a marked indentation in the 100 fathom contour such that the continental shelf is only 25 miles or less in width in these places. on the Malabar coast, in general, there is a gradual slope on the sea bottom upto 100 fathoms and then there is a sudden steep fall in the depth. But in some places there are marked deviations in the slopes. For example, along the Mangalore-Cochin section and at Cape Comorin, the continental shelf slopes gradually to about 65 fathoms and then drops ram plaly to 1000 fathom 1ine. Also at Quilon, upto 190 fathom ine, the slope is gradual. Then the shelf rises seaward to 170 fathoms after which 1 plunges rapidly away.

Location - The harbour is located in Lat. $9^{\circ} 58^{\circ} \mathrm{N}$ and Long. $76^{\circ} 14^{\prime} \mathrm{E}$ at a distance of $100 \mathrm{miles}$ from the southernmost $t$ ip of India. It is situated in the sheltered area of a backwater, a large expanse of water which is formed between a long narrow peninsula and the mainland, 3 miles east of cochin. At cochin, there is a gap, $1500 \mathrm{ft}$. In width, in the peninsula, so that inside that gap the main harbour, at once, opens 6000' wide causing all the waves entering from the sea outside the gap, to get absorbed in the backwater. Most probably, that gap was the result of a break-through during the earlier centuries from an unknown cause. On one side of the gap lies the town of Cochin and on the other side an island on which vypeen is the most important town. The back-water is navigable for country crafts for about $125 \mathrm{sq}$. miles extending as far as 40 miles south of Cochin (FIg. 8). It drains and partly covers some $5,000 \mathrm{sq}$. miles of low country. The southern end of the Western Ghats drains into the Vembanad Lake which is a large expanse of water forming the southern portion of the backwater and it seems possible that the long peninsula upto Cochin which is of alluvium was formed by the silt brought down from the Western Ghats and 
drained into the Vembanad Lake. Similarly, the island of which Vypeen is the southernmost extrem1ty was, probably, formed by the silt brought down from the Western Ghats by $t$ Periyar river situated a fow miles north (F1g. 8). The mouth of this river is at present silted up. The foreshor of Vypeen and Cochin consist of gran1to1d gniess sand which had its origin at the Western Ghats and which was brought $t$ the shore by the 11ttoral forces.

\section{SEDIMENT PROBLEM}

Cochin harbour may be classifled as a channel harbou in t1dal estuary. But unlike other channel harbours, it $\mathrm{b}$ many pecullarities. Its maln features are (1) there are $n$ rivers of 1mportance especially near Cochin, which feed int the back-water and the only opening is at Cochin where the backwater discharges into the sea. Therefore all the smal rivers with the1r sediment of silt and clay drain first int the backwater. (2) Due to the largeness of the backwater and high rainfall of 120" per year with about $80^{\prime \prime}$ during SW monsoon period, the quantity of water flowing in and out is so great that the botton of the backwater and the sea are covered w1th mud moved back and forth by the tides. The s11t and mud since they require only small velocities for transportation e1ther in suspension or at the botton are ca ried further 1nto the sea leaving the area near the coastil to the covered by sand brought by littoral forces. (3) $\mathrm{Th}$ wind and therefore the waves at the harbour are light and small creating a situation favourable for the settlement of sediment particles in the lee of the gap and at other place where the velocities are low. (4) Along the coastilne $t$ source of supply for littoral transport is the eroded mater of the coast since there are no 1mportant r1vers to supply such material. Recent surveys show that as much as $40^{\prime}$ ar eroded away at some places south of Cochin during the $S$. W. monsoon although $20^{\circ}$ of the coastal strip is restored back other times. (5) In the harbour and the entrance channel, the main trouble is from the silt brought down by the tides from the backwater area. At times of flood tides, some of the s11t taken out during the ebb tides finds 1ts way back along with the littoral materlal and settles in the lee of the peninsula at low velocity areas. (6) Some of the lit. toral material finds its way into the lee of the harbour er trance due to diffraction of waves. By diffraction, the wave helghts and thus the wave energy are reduced thereby allowing the sediment to settle down. (7) At the harbour, the amount of 11ttoral drift settling dow in the entrance channel is small as compared to the silt carried by the til from the backwater.

Surface currents - The surface currents follow to a great 6 tent, the wind direction of the prevalilng season (Figs.7, 10). Along the west coast, at no time do they exceed 12 miles per day. This being the surface velocity, the bottc 
SEDIMENT MOVEMENT AT SOUTH INDIAN PORTS

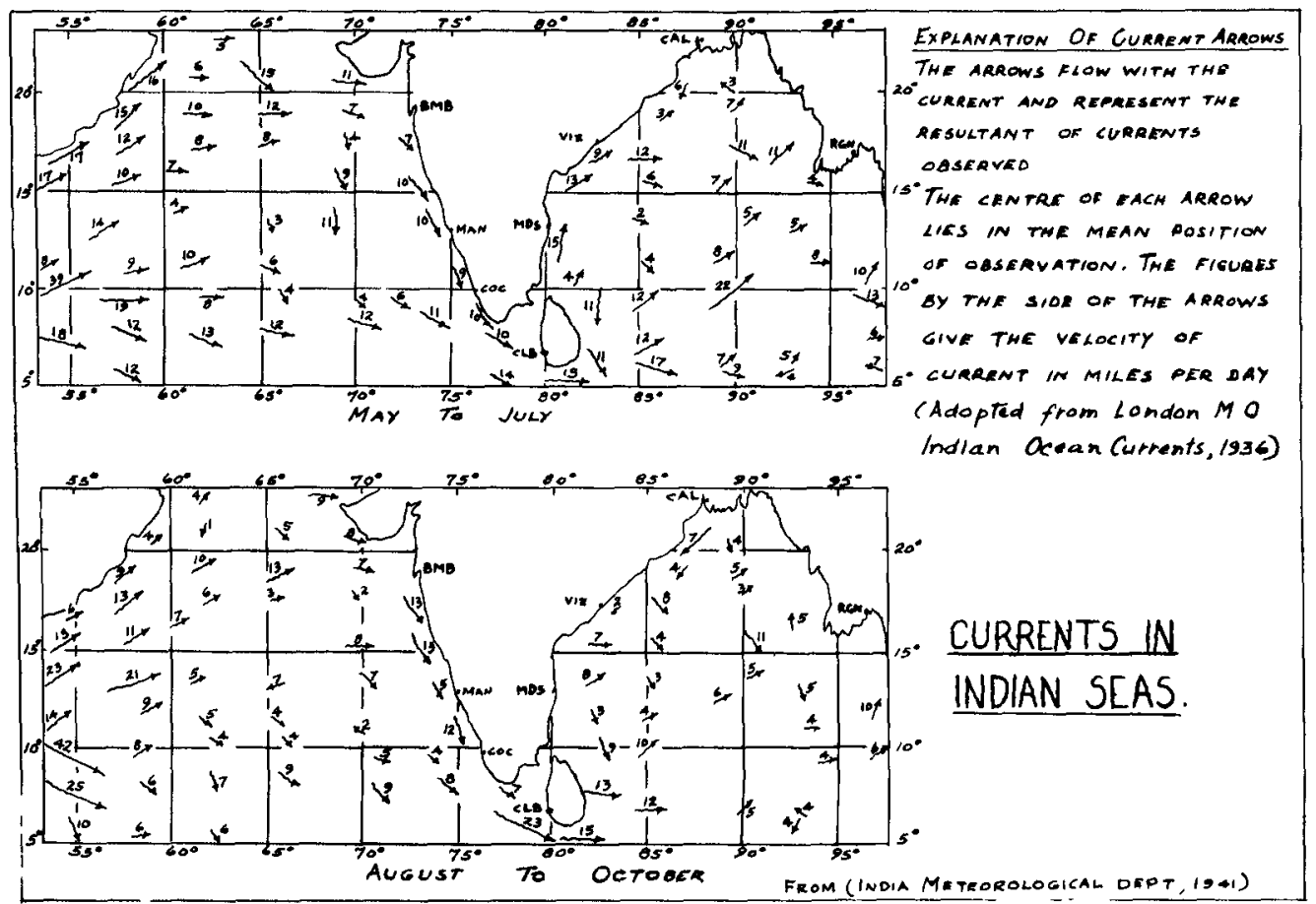

Fig . 10. Currents in Indian Seas - May to October.

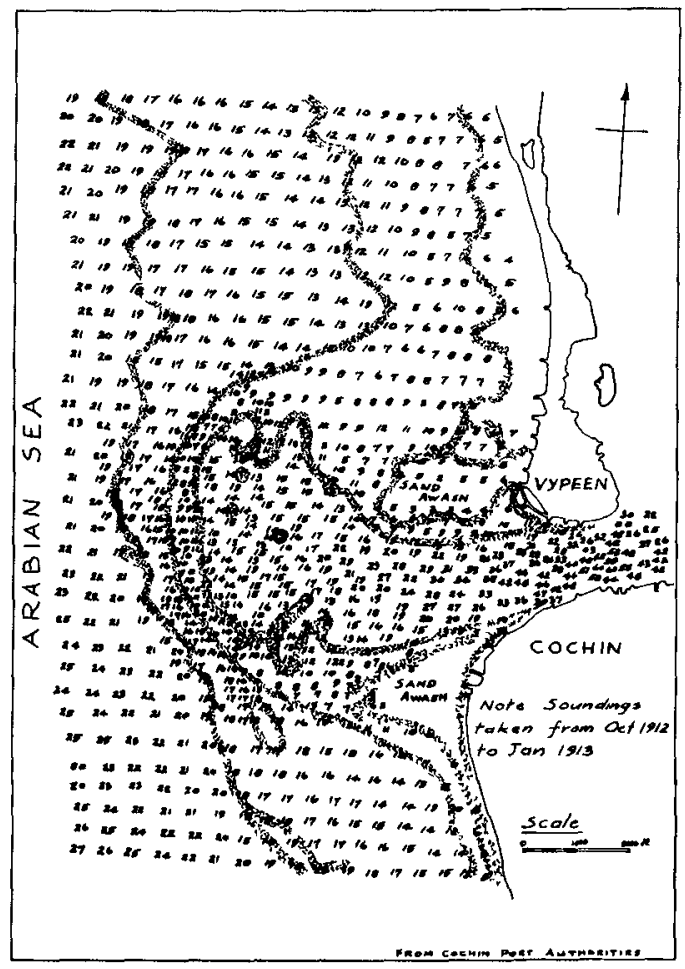

Fig. 11. Cochin harbour: Outer bar in 1913 . 
velocity is still less and also since the currents act at some distance away from the coastline, their effect on litte ral drift is very slight and negligibie.

Tides - Along the Arablan Sea Coast, as in other places, the tides change according to the locality. From about 100 miles south of Madras on the east coast to Mangalore on the west coast, there are no tidal streams along the coast exce] fust at the mouth of the rivers. Southwards from here dur. Ing the flood tide, the tidal stream comes from the nortwes especially at Cochin. A pecullarity of the tides at Cochil is that they are susceptible to the influence of winds. A the Cochin harbour entrance, the ordinary spring tides rise to $3^{\prime}$ creating currents from $1 \frac{1}{2}$ to $2 \frac{1}{2}$ knots. They extend for 40 miles southwards in the backwater area where the spring range may be as low as $8^{\prime \prime}$. Neap tides rise $1 \frac{1}{2}$ to 2 ft. creating currents of 1 to $1 \frac{1}{2}$ knots. However, the tide are not regular especlally during the monsoons due to fresh water discharge. Depending upon the season, the ebb tide which is generally swifter than the flood tide continues fo. a long time lasting 10 to 11 hours during the monsoons with current of $3 \frac{1}{2}$ knots and for 7 hours at other times. At ordinary times during flood tides, the ingoing current star at about 2 miles north and south of the harbour entrance w1 a velocity of $1 / 2$ to lt knots which during the ebb tide mer iy reverses its direction. The effect of the tides at Cochin is to move back and forth, the backwater silt and th ilttoral drift.

Waves and Littoral Drift - The waves that apprsach Cochin harbour have a maximum height of $2 \frac{1}{2}$ at a depth of $15^{\prime}$ and period of 10 seconds during the $S$. Wo monsoon season. At other times, during the calm and fair weather periods, the wave helghts vary from $1 / 2^{\prime}$ to $1^{\prime}$ with a period of 10 secon while the $N$. E. monsoon season experiences a maximum height of $2^{t}$ and a minimum helght of $1 / 2^{\prime}$, the period remaining th same at all times.

The direction of 11ttoral drift varies at different times of the year depending upon the direction of approach the waves. During the fair weather season and the beginn1 of the N. E. monsoon season since the waves are WNW, NW or westerly in direction, the littoral drift is southwards. Ho ever, during the $S$. W. monsoon season, with the waves approaching from WSW or $S W$, the littoral drift moves northwards. With the $S$. W. monsoon being stronger and more per sistant, the not littoral drift is northwards.

The quantity of littoral drift that moves along the coast is small dve to the reasons mentioned earlier. Recer. surveys show that the net northerly drift is not greater tr. 42000 tons per year as against 1 million tons per year traveling northwards along the east coast. 


\section{SEDIMENT MOVEMENT AT SOUTH INDIAN PORTS}

An 1dea as to the effect of 11ttoral drift and the backwater silt on the entrance channel, foreshore and the harbour proper can be obtained from a review of the previous and present history of the cochin harbour.

Outer Bar and Channel - Before the outer navigational channel was dredged, there was no easy access for ships to enter into the harbour proper due to the presence of an outer bar (FIg. 11) which was formed in the form of a horse-shoe by the freshets discharging from the backwater carrying silt brought by the monsoons. The bar was formed at a maximum distance of $1 \frac{1}{2}$ miles from the harbour entrance between the 2 fathom contours. Probably this was the zone where the effect of ebb $t$ ide was balanced by the opposing velocity of the incoming waves resulting in low velocities ideal for sediment settlem ment. The bar was about $600^{\prime}$ wide with a long flat slope on the harbour side and a steep slope on the sea side. The bar was somewhat semi-circular in shape with a radius of about 1 mile and a periphery of 3 miles but narrower on the left shoulder and wider on the right shoulder due to the predominence of the $s_{\text {. }} w_{\text {. swell. At its shallowest place, the top }}$ was 10" below low water ordinary spring tide level at the worst season of the year. Dense sand, most probabiy brought by the littoral drift, existed at the top of the ridge while silt, mud and clay brought by the ebb tide from the backwater were found below at a depth of 20'. The depth on the bar varled very little for a long period of 89 years till it was dredged in 1922 to make way for the navigational channel. Even after the $S$. W. monsoon, the mean depth over the bar was never less than 9\%. This may be explained from the fact that the 2 ' waves generally prevalent throughout that season could generate sufficient velocity at that depth to prevent the sediment from settlement. In some instances, it was noticed that the bar moved farther from the entrance during the fair weather season, as much as $600^{\prime}$ from its original position while it was restored back to its original position after the monsoons. This gives further evidence of sediment movement under the sea towards the shore under the action of differential velocities at the bottom especially during heavy seas.

Outer Navigational Channel - A navigational channel which is made sufficiently deeper than the adjolning areas to allow for the safe passage of ships into the sheltered area is an essential requirement of a harbour. But with greater depths in the channel, sediment in motion settles down in this area. Therefore where the littoral drift is great or where the sediment brought by the rivers or bays in which the harbour is situated is great, the problem of maintenance of the channel by dredging becomes an impossible task. Some arrangement by which the sediment could be trapped and disposed off before it reaches the channel is essential in such situations. Luckily at Cochin harbour, the littoral drift is sma11. 


\section{COASTAL ENGINEERING}
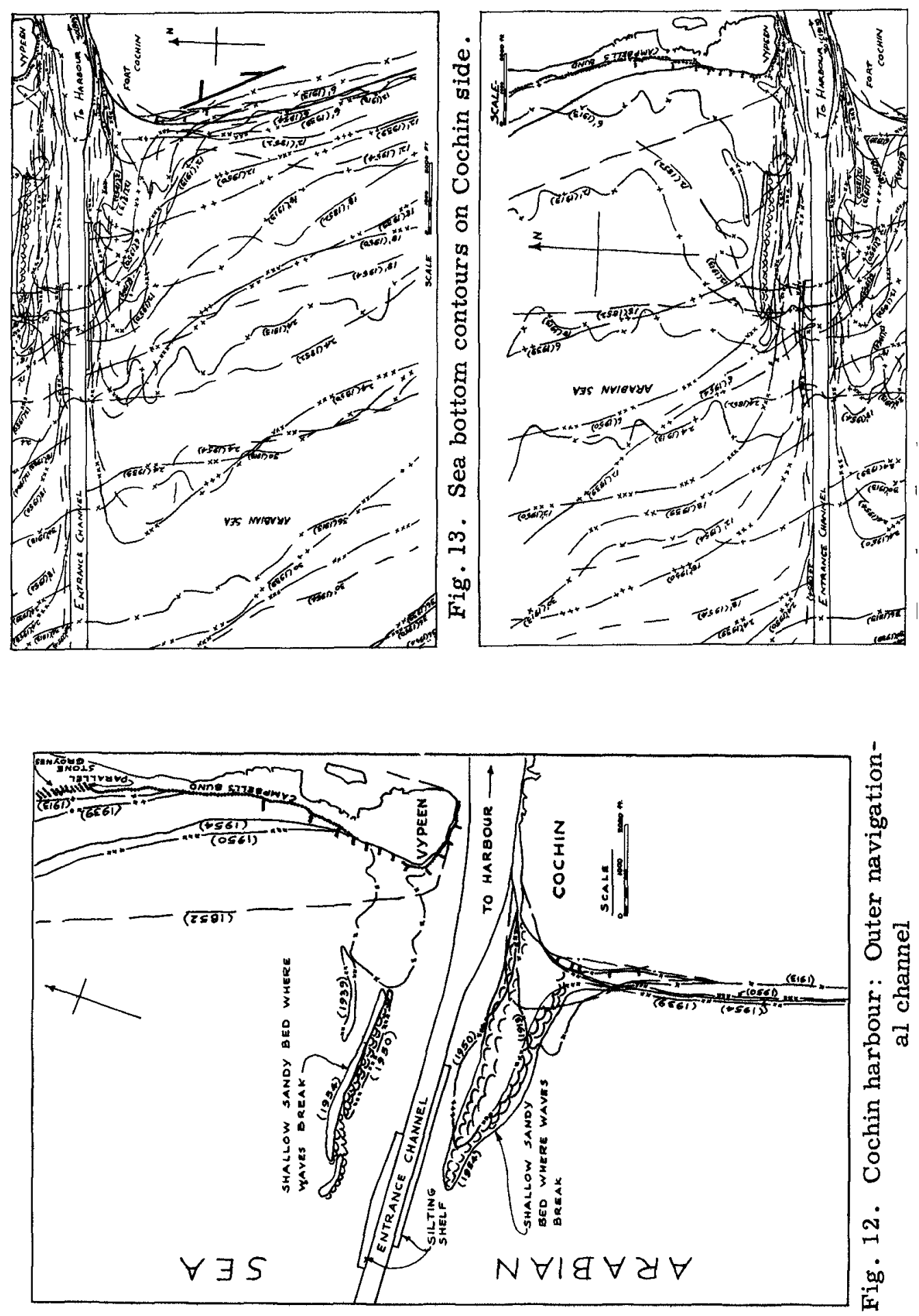
Similarly the silt brought by the backwater settling down in the channel is also not great so that maintenance by dredging for about 4 months a year is sufficient to keep a safe minimum depth of $32^{\prime}$ at ail times with the maximum depth of 38, below L. W. O. S. T. The channel which extends upto the $3^{\prime}$ contour is $17000^{\prime}$ long, $450^{\prime}$ wide and extends about $9000^{\prime}$ beyond the old location of the bar. At that local1ty where the bar used to be formed, a silting shelf $100^{\prime}$ wide and $4000^{\prime}$ long on the south side of the channel and a similar silting shelf $100^{\prime}$ wide and $3000^{\prime}$ long on the north side. (F1g. I2) are provided to trap the 11ttoral drift and silt from the backwater and also to compensate for caving in of the sides of the channel. It is worthwhile to mention that a depth of about $40^{\prime}$ is always maintained at the entrance by the strength of the ebb tide.

The alignment of the channel is, by itself, important. At Cochin, since the prevaling sea swell and chlef winds are from the WSW, fair weather winds and waves from WNW, the main ilttoral drift northerly along the coast and ebb current west by north, the channel is dug pointing due west so that it would have the least trouble from all the conditions existing in that region. By or lenting the channel due west (I) the ebb tide is allowed to join the ocean currents with the le ast opposition, (2) the flood tide runs up the channel in its natural direction, (3) the dredging operations are made possible in not too rough seas and (4) the littoral drift is intercepted in as littlo area as possible. Upto the present time, the maintenance of this channel has not been a troublesome factor.

Erosion and Accretion of the coast and Sea Bottom near the Harbour -

With the northerly drift of the littoral material suddenly arrested by the ebb flow from the backwater and partly allowed to settle down on the cochin side and partly deflected away towards deeper reglons of the sea, the narrow spit on the Vypoen slde beyond the gap is starved of the necessary iftoral material resulting in considerable erosion on that side. By 1913, the narrow sp1t on the Vypeen side was erodIng so fast that protective works in the form of stone faced bunds called Campbell's bund (F1g. 12) were constructed for the lower part of the spit but in the upper part the spit was st 111 eroding at $20^{\prime}$ to $30^{\prime}$ per year. By 1920 , there was nearly a mile of this portion in a dangerously vulnerable state with only a narrow strip of land of a few feet in width lying between the backwater and the sea. In order to arrest the complete erosion of this narrow spit and thus save an inportant protection to the harbour 1t was then decided to trap the northerly drift material by the construction of a serles of non-continuous stone groynes running nearly paraliel to the shore and overlapping each other in an eschelon fashion for a distance of two miles (FIg. 12). These proved very 
effective and since then, this coastline had gradually buil up by accretion of the ilttoral material. They reduced th force of the waves attacking the beach, induced the waves $t$ travel behind the groynes thus allowing the littoral mater to settle down in the calm area, and being nonmcontinuous were susceptible to less erosion on their outer toe. Thes were found to be far more effective and stable as compared a continuous seawall at this locality. As shown in the $f_{1}$ gure the coast on the Vypeen side is gradually being restor to the profile as 1t existed in 1852. However, it looks a if it will never attain that profile. A study of the shor profiles will show that while there was gradual accretion $c$ this coastal strip upto 1950, since then, there had been er sion at a rate of $50^{\prime}$ per year in the upper regions. It seems therefore that the maximum accretion was reached in 1950 and that the equilibrium profile if one ever exists, lies between this profile and profile of 1913. On the otr hand, on the Cochin foreshore, there had been neither appre clable accretion or erosion (Fig. 12) except for the forma. tion and gradual extension of a sandy shoal parallel to the entrance channel.

Gradual silting up of the sea bottom is also one of the ways by which littoral drift manifests itself when equ' librium conditions are disturbed. At the Cochin foreshore the bottom is slowly advancing towards the sea at a rate of $90^{\prime}$ to $100^{\prime}$ per year beyond the $24^{\prime}$ contour and $50^{\prime}$ to 70 per year between the $12^{\prime}$ and $24^{\prime}$ contours (F1g. 13). At depths less than 6', the conditions have, generally, been stable since 1937. On the vypeen side, the rate of advan is greater with about $170^{\prime}$ per year beyond the 24 ' contour (F1g. 14). At depths less than 24', the bottom advances more rapidly at a rate of $220^{\prime}$ to $250^{\prime}$ per year. This is contrary to what happens on the Cochin side and is most pri bably due to the effect of the stone groynes. It is in teresting to note that from 1852 to 1913, there was erosion of the bottom on both Cochin and Vypeen sides at a rate of $15^{\prime}$ per year. The considerable foreshore erosion on the Vypeen side and to lesser extent on the Cochin side also $\mathrm{h}$ pened at the same time before the protective bunds and groynes were bullt on both sides.

Sandy Shoals - The effect of ebb flow on littoral drift is manifested in another way namely in the formation of sandy shoals parallel to the sides of the entrance channel (Fig. 12). The sandy shoal on the south side is formed by the sudden stoppage of the northerly littoral drift by the ebb tide causing it to settle in the adjacent areas while the sandy shoal on the north side is formed when the littoral drift taken into the backwater area during flood tide is taken out during the ebb tide and thrown into the low velo city region on the north side adjacent to the channel. T situation is reversed when the littoral drift changes its direction from north to south so that in both cases, the 


\section{SEDIMENT MOVEMENT AT SOUTH INDIAN PORTS}

sandy shoals bulld up gradually. The rate of advance of the se sandy shoals is on the increase from $15^{\prime}$ per year upto 1913 to $80^{\prime}$ per year between 1913 to 1950 and $200^{\prime}$ per year since then. The rapld advance of the sandy shoals seems to be Intimately connected to the advance of the sea bottom.

It is possible that the gradual advance of the bottom and also of the sandy shoals towards the sea, though not a threat to the maintenance of the channel upto the present time, may be a factor to be reckoned with later on. The increase in the amount of dredged materlal from the channel and the backwater may be due to this advance.

Sediment Samples - Bottom sediment samples taken at various places inside and outside the harbour show the presence of ilttoral drift material (FIg, 15, 16). Samples 1,2 and 3 namely, those taken from the coastal region and the harbour mouth show a common origin namely, the coarse grained sand brought by the littoral drift from along the coast. Samples 4 to 8 taken at increasing distances from the harbour mouth within the backwater show a progressively finer texture in the material indleating the clay and alluvial material that have their origin in the Western Ghats and Invarlably brought down by the monsoons.

Effect of Wave Dfferaction on sedimentation - The sediment settlement due to wave diffraction, a phenomenon (Johnson, 1951), (Dunham, 1950) by which waves are propagated into the sheltered region of a breakwater or breakwater gap has a direct bearing on the construction and maintenance of a harbour formed in the sheltered region. By diffraction, the regular wave train is suddenly interrupted and the heights of waves entering the sheltered region are progressively reduced, thereby creating a condition by which the sediment settles down in the region of low velocity. In the case of cochin harbour when the waves pass into the harbour through the nam tural gap, $1500^{\prime}$ In width, they are diffracted. Since the waves approach the gap obliquely, the reglon behind the Cochin peninsula namely, the Mattanchery channel (P1g. 17) becomes an Ideal place for sediment settlement due to diffraction. The sediment thus deposited is taken into the interior of the Mattanchery Channel by the flood tide resulting in shoaling of that channel while there is practically very little siltIng in the Ernakulam Channe l. Part of the sediment deposited by the diffraction on the Vypeen side and the Ernakulam Channel finds its way out and deposits on the northern sandy shoal (F1g. 12).

\section{MUDBANKS ALONG THE WBST COAST}

The term mudbank or mudlump is used to represent islands of mud or clay that show up along the coast. They are rare in occurrence and are formed only under favourable con. ditions. Along the west coast of Southern India and at the 
Mississipp1 river mouths off the Gulf of Mexico (Morgan, 1951), these form a un1que phenomena and the author knows of no other locality where mudbank activity has been reported. The formation of mudbanks is independent of the littoral drift action but $1 t$ is described here since it forms a part of the sediment activity along the coast. Their formation and activities along the Malabar coast are in many ways simi lar and dissimilar to those of the mudlumps of the Mississ1pp1 river delta. Their activities were greatest upto 1938. Since then, many have disappeared and many have $r$ isen in other places. Before 1938, there were 4 well known mudbank off this coast, (Bristow, 1938) namely one at Alleppy (F1g. 8 ), one at Narakkal just north of Vypeen and two at or near calicut. There may have been a few more at that time but they were not well known. Three of these mudbanks were either near or at the mouth of rivers while the fourth one Alleppey though not anywhere near a river mouth was separate from the large Vambanand Lake only by a narrow alluvial str1

Before the harbour was established in the backwater, these mudbanks were a great boon to ships and country craft: since they had a peculiar property of completely damping eve the roughest waves along their seaward slopes and elsewhere making it possible to unload cargo or take shelter in their vicinity. But their peculiar behaviour such as their sudde appearance above the sea and their sudden disappearance bel the sea without any previous activity, their southward and northward movements, and their occasional eruptions have ber the subject of speculation and study for a long time.

Their Nature, Origin and Act1vity - All the mudbanks are co ined within the main body of the alluvial coastal strip on the west coast namely the coastline from Calicut to Cape Co morin (Fig. 8). The sea bed off this coast is also mainly mud stretching as far as the 20 fathom line roughly $17 \mathrm{mile}$ distant from the coast. The mud on the banks and the sea bottom in these areas has the same property, indicating com mon nature and origin. It is fine grained with 70 percent of the particles being clay having an effective diameter of $0.0015 \mathrm{~mm}$ (PIg. 18). Borings of the sea bottom show that the alluvial material lying to a thickness of $400^{\prime}$ to $600^{\prime}$ above rock was most probably brought by the past and presen rivers and the backwater from the Western chats. The mud itself is dark green in colour when wet and being very fine it is soft and gives an olly appearance. But when it becomes dry, it loses 1ts olly composition, and becomes hard like ordinary mud. Though it is soft at the surface, it 1 compact at the bottom and forms a good holding ground.

The origin of these seem to be the rivers. In almc all cases where mudbanks appear, rivers are at moderate di: tances and even at Alleppey, an opening had once existed ar it seems 11kely that a water bearing stratum exists in that locality and elsewhere at great depths below the surface 


\section{SEDIMENT MOVEMENT AT SOUTH INDIAN PORTS}

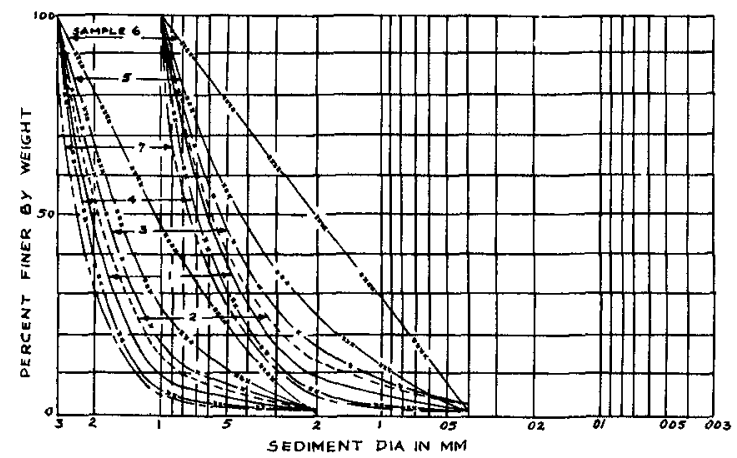

Fig. 15. Cochin harbour. Sediment analysis

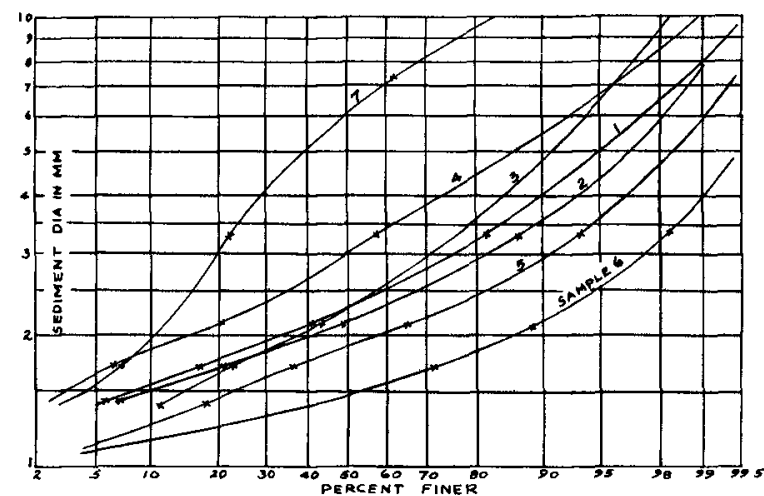

Fig. 16. Cochin harbour: Sand analysis

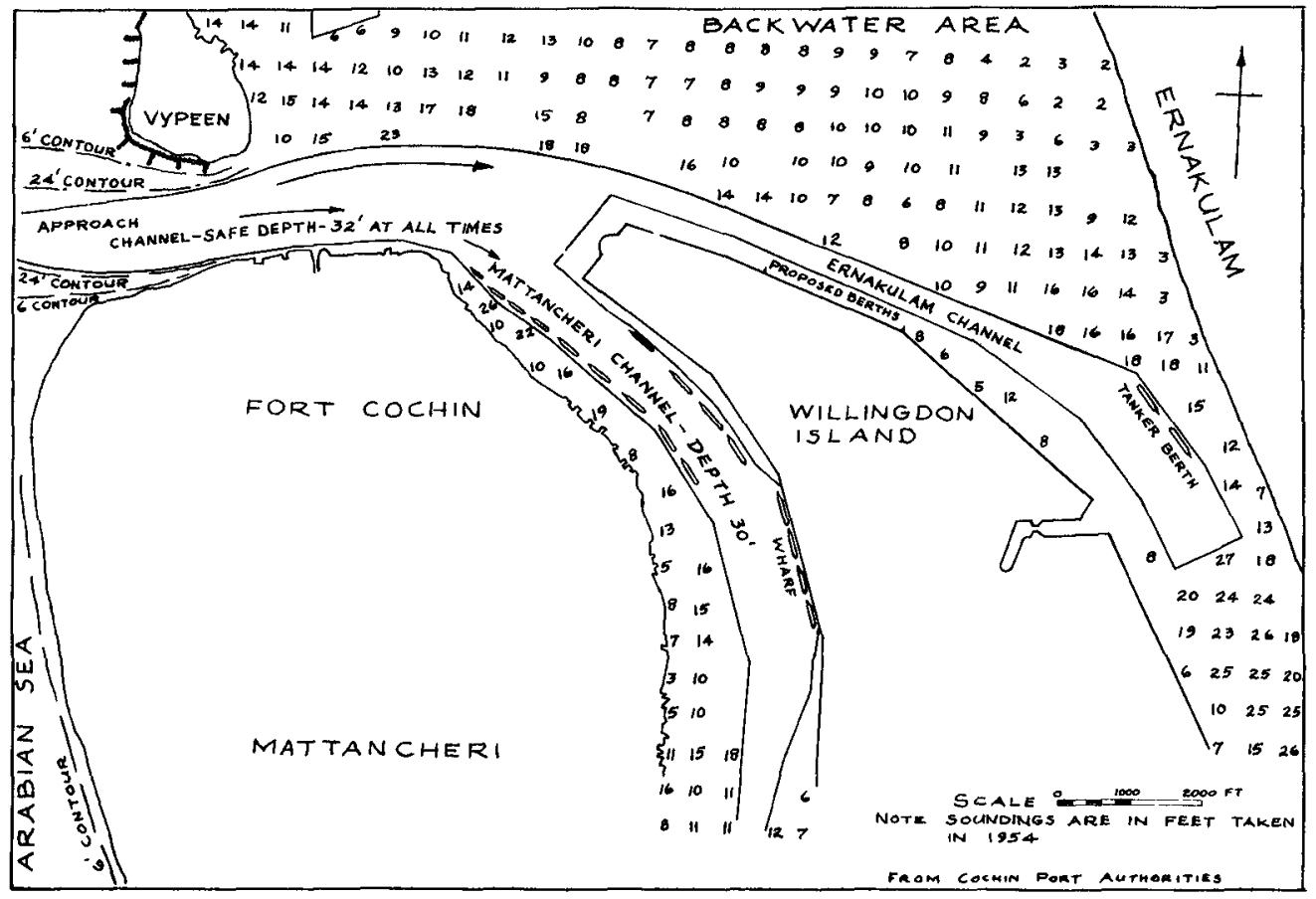

Fig. 17. Cochin harbour: Navigational channels in main harbour. 
COASTAL ENGINEERING
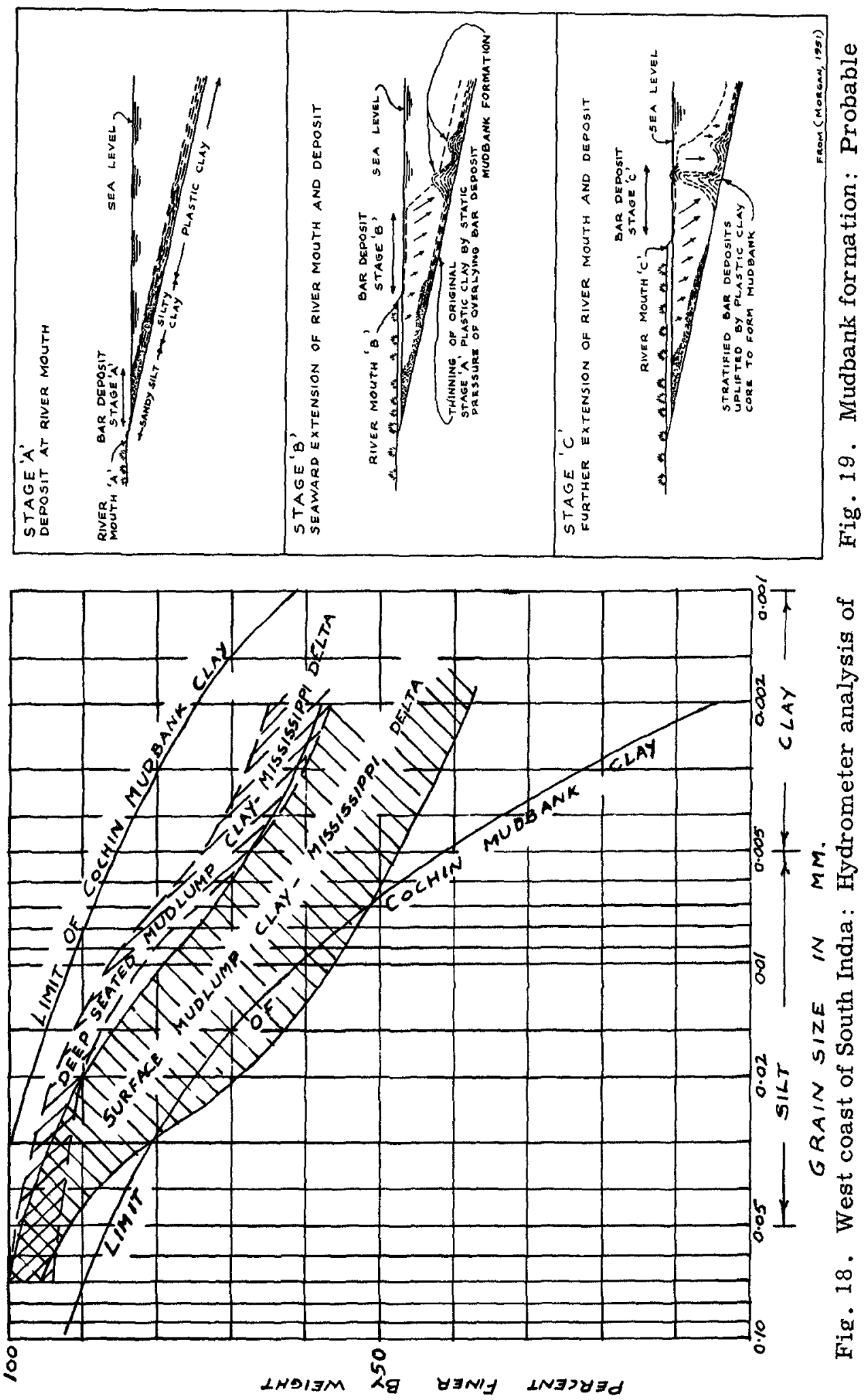
through which mud from the backwater is carried out into the sea and iffed up as mudbanks. Bore holes at Cochin indicate the presence of water bearing strata which probably keep the mud in suspension at those banks. That water bearing strata exist along the coast may also be inferred from the fact that frequent eruptions and rising of mud above water and the sudden appearance of new mudbanks occur only during high water periods in backwaters. Thus it seems that the mudbanks may have been formed due to the following causes elther separateiy or together:-

(1) by the gradual deposition of detritus malnly mud and clay brought down by the rivers;

(2) by the gradual throwing up of silt and mud through water bearing strata connecting the beckwater and the sea; and

(3) by the sudden throwing up and re-deposition of mud, already in existence at the bottom, due to rough seas and selsmic disturbances.

When mudbanks are formed due to category (3), they may not be stable and may disappear as fast as they appear as 1 t had happened at Callcut and Alleppey on a few occasions.

In general, they are formed from river deposits and their processes of formation may be ideally represented (Morgan, 1951) in three stages (F1g. 19). In stage A, the sediment brought by the river which consists of plastic clay, silty clay and sandy silt is deposited at the mouth of the river with the fine plastic clay farthest from the river mouth and the coarser sandy silt nearest to the mouth. In stage $B$, since the quantity of sandy silt and silty clay brought by the river is greater than plastic clay, their bar deposits grow faster so that they overlie the plastic clay deposit of stage $A$, resulting in the squering ahead of plastic clay from thelr load pressure. During this process, the plastic clay breaks through the thin forward edge of the bar deposit starting the initial formation of the mudbank. In stage $C$, with the bar deposits and plastic clay increasing in quantity, the mudbank is forced to the surface and with the bar deposit surrounding it, it becomes a localised bank. A premrequisite to the formation of the mudbanks is that the river sediment as well as the sea botton sediment should consist of plastic clay, silty clay and sandy silt, a condition that exists along this coast.

The Alleppey and the Narakkal mudbanks when they existed used to move generally towards the south due to the stronger currents from north to south. It may be noted that the southerly direction of the currents exists for 8 months of the year. These currents are stationary for a month and for the other three months they flow from south to north. The 
southward movement of the mudbanks is exactly opposite to the movement of the littoral drift which is due to the fact that the coarser ilttoral material moves in the shallow wati zone close to the shore where it is subjected to direct wavi action and moved northwards by the longshore current. Thy mudbanks which are slightly farther away in the sea come under the direct influence of the southerly currents, which cause their movement because of their finer texture. Thesi mudbanks gradually grow in size being nourished by the rive. or by additional material thrown up from the sea bottom unt they are finally broken up by forces such as waves, swells, cyciones and seismic disturbances. Sometimes these mudban: used to move suddenly to the north again due to the norther currents, or disturbances in the sea or h1gher flood discharges from the backwater in the case of the Narakkal mudbank. During its southerly movement, the Narakkal mudbank crossed the harbour entrance channel some years ago and elther disappeared into deeper areas or dissipated away. T original Alleppeg mudbank also suffered a similar fate. Ma new mudbanks have been appearing and disappearing along thi coast though at present, there are none near the harbour.

The unusually calning effect around the mudbanks due to the damping of the incoming waves may be attributed to $t$ causes namely (I) the increase in kinematic viscosity of th suspended mud acting like a jelly and (2) the increase in $t$ friction drag on the slopes of the mudbanks. The mud is always kept in suspension by the action of the Incoming wav or by possible fresh water springs at the sea bottom.

These mudbanks are different in many ways from the mudlumps of the Mississippi river delta namely (1) they are also formed in places other than the mouths of rivers (2) they are generaliy in motion in the direction of coastal cu rents (3) they dampen the waves completely and no wave brea around them (4) steep slope is not a necessary criterion fo the ir formation and (5) their activities such as eruptions, and throwing up of mud are not frequant phenomena.

\section{MANGALORE PORT}

Mangalore port is a small port situated at Latitude $12^{\circ} 52^{\circ}$ N and Longitude $74^{\circ} 51^{\circ} \mathrm{E}$ along the west coast, nor of Cochin (Fig. 8). Unlike the Cochin harbour which is ideally situated in a large backwater, this port is formed the junction between the Gurpur river, the Netravat1 river and the Arabian Sea (Fig, 20). A sand sp1t (Fig. 20) 3 miles long and $300^{\prime}$ wide $110 \mathrm{~s}$ between the Gurpur river and the sea. Similarly another spit of a smaller size separat the Netravati river from the sea so that a calm area of wat exists behind the gut formed by these two sand spits.

Accretion and Erosion - This harbour may be classified a cl nel harbour in tidal estuary and it has all the problems er 


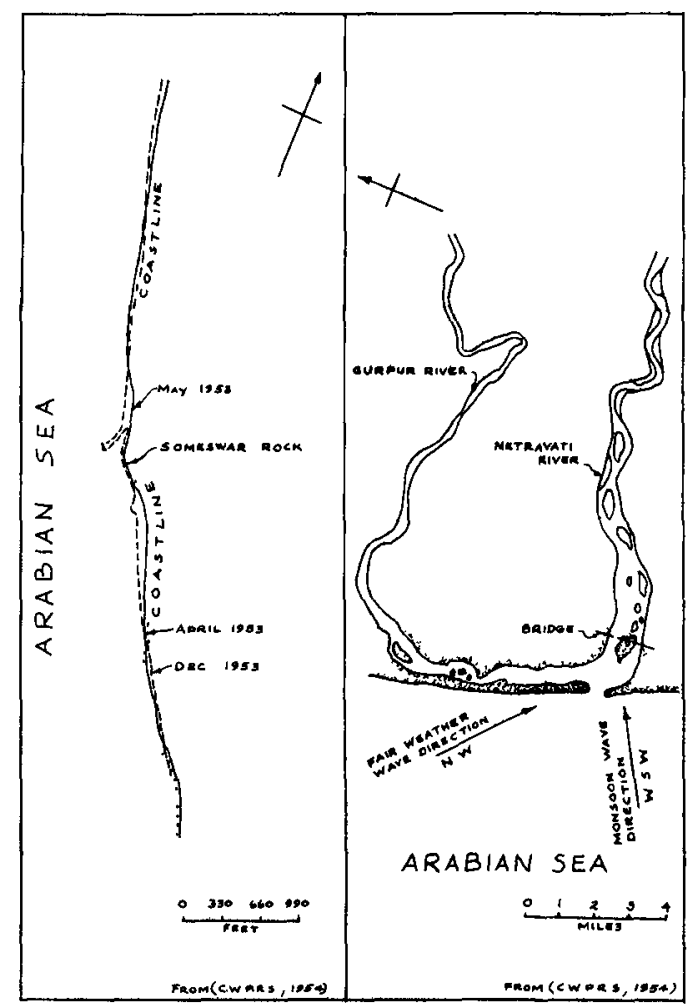

Fig. 20

Fig. 21

Location

Neighbouring coastline

Mangalore Port

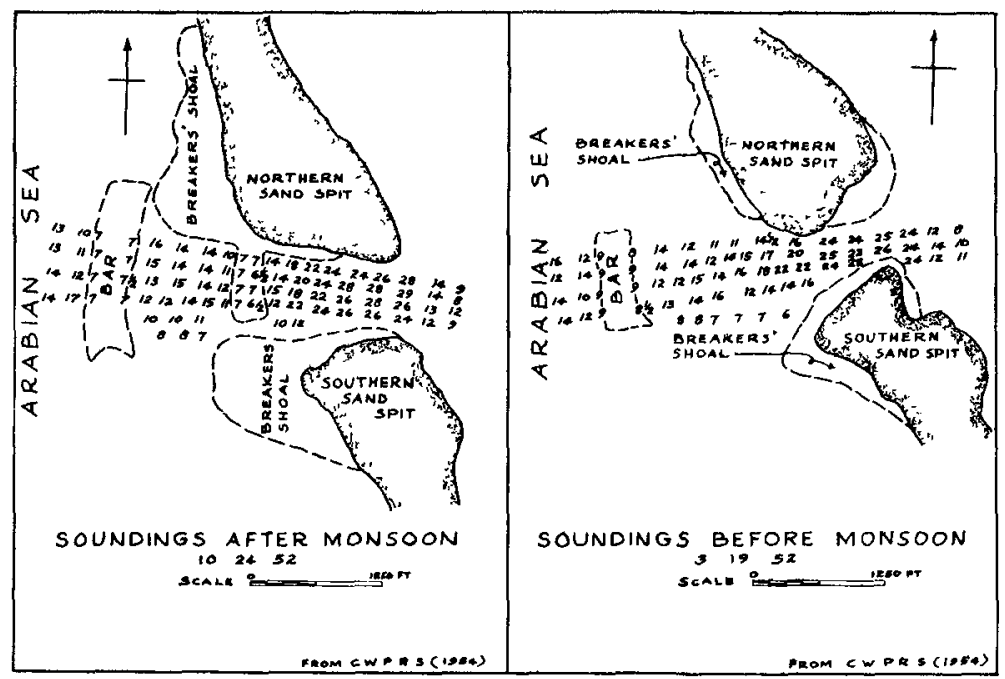

Fig. 22. Mangalore Port: Outer bar 
countered in such harbours. Just outs1de the entrance, as was the case at the Cochin harbour, there is a large bar (F1g. 22) over which the depth varies from $7^{\prime}$ to $9^{\prime}$ below L. W. 0. S. T. It is about $700^{\circ}$ in width, east and west, and begins from about 2000 feet due west from the entrance. As shown in the flgure, the depths over the bar decrease after the monsoons and are greater before monsoons. Unlik at Cochin where the backwater discharges only s1lt and clay capable of being carried further into the sea, the two r1vers, Gurupur and Netravat1, carry enormous quantity of coarse sand varying in dia. from 0.5 to $0.65 \mathrm{~mm}$. which settles inside and just outside the entrance to the harbour re sulting in heavy shoaling in the se localities. The north and south sandy shoals increase in size after the monsoons due to the river deposits and are reduced in fair weather, most probably, by the littoral currents, on an average, there is change in helght over the shoals of about 3 feet with quantity of accretion or erosion of 0.15 mililon cyds roughly 300,000 tons per year. (Central Water \& Power Rem search Station, 1954).

L1ttoral Drift - The net 1ittoral drift moving northwards along the coast is smaller when compared to this quantity $c$ river material and is of the order of 200,000 tons per year as indicated by the erosion and accretion at Someswar, a re outcrop 3 miles south of the gut (FIg. 2I). The sources this littoral material are the two rivers Gurpur and Netravat1 which have a maximum discharge of 60,000 cu.ft. per se cond and 120,000 cu.ft. per second respectively. This lit toral drift is about five times greater than at cochin and most probably localised in this area. The direction of th littoral drift is the same as that at Cochin with its move. ment northwards during the $S$. W. monsoon when waves reach $t$ shore from WSW and southerly during the falr weather seaso: from December to May when waves with a period of 17 sec. a wave length of $1500^{\prime}$ and a helght of 2 ' $^{\prime \prime}$ in deep water res the shore from a northwesterly direction. The net littor: drift is northwards due to the stronger and persistent $s$. I monsoon.

The fact that 11ttoral drift and river deposits are large with no method of disposing off the coarse material deep into the sea or elsewhere except by continuous dredgil makes the maintenance of this harbour very expensive and a: such, the improvement of this harbour into an all-weather port has been abandoned for the present. At present, it only an open roadstead (Ministry of Transport, 1950) close during the S. W. monsoon period from May to September. I fair weather, vessels $11 e$ in the sea at a distance of two miles from the harbour entrance

As a comparison with the Cochin harbour, it may be pointed out that at Mangalore (1) littoral deposit is five times greater (2) the river deposits are so coarse and gre: 
in quantity that their disposal by dredging is very costly (3) the formation of the large sandy bar at the entrance will be a constant trouble to be encountered with when a navigational channel is provided and (4) 1deal conditions such as a large backwater with no silt bearing rivers of importance feeding into 1t, small littoral drift, large obb flow and lesser maintenance work as they exist at Cochin are not found at Mangalore.

\section{EAST COAST TO SOUTHERN INDIA}

The east coast of India which extends from Cape Comorin to the mouth of Ganges has a coastline of 1300 nautical miles (F1g. 8). In the south, the stretch of coastline between Cape Comor in and Pamban (F1g. 8) is called the west coast of Gulf of Manar and this coast is shielded by the island of Ceylon. From Pamban to about Lat 1tude $16^{\circ} \mathrm{N}$, the coastine is called the coromandal coast. The remaining coastline is divided into the Circars coast (upto Latitude $1923^{\prime} \mathrm{N}$ ) and the Orissa coast upto the mouth of river Hoogly.

Wind System - Table 2 below shows the average direction and force of wind system along the east coast (Meteorological office, 1940, Hydrographic Department, 1953).

Land and sea breezes are also a marked feature along this coast especially during the transition seasons. However, NE and SW monsoons dorninate the surface winds of the Bay of Bengal and the east coast. SW winds other than those of the S.W. monsoon can be observed in the Bay of Bengal in March, April and May due to the heating up of the land areas to the north and east. October is the only month when the wind and weather are variable to a large extent.

\section{MADRAS HARBOUR}

The east coast of India on which Madras harbour is situated, is bounded by a chain of hills or mountains known as the Eastern Ghats running roughly parallel to the coastline (F1g. 8). Unlike the Western Ghats, they are not continuous and consist of numerous hills, some of them rising upto 5000 feet in elevation. They are situated inland with a broad strip of low lying land of alluvium between them and the Bay of Bengal. Southwards of Madras, the width of the coastine is about 80 miles as compared to a narrow stretch on the west coast. Northwards of Madras it narrows to a width of 30 miles. Thus the east coast is an eroding coast being exposed to the prevaling waves.

ORIGIN AND EFFECT OF LITTORAL DRIFT

Between the Western and the Eastern Ghats lies a plateau varying in elevation from 1000 feet to 3000 feet. Most of the rivers in south and central Indla which have their 
Table 2.

\begin{tabular}{|c|c|c|c|c|}
\hline Month & $\begin{array}{l}\text { Wind } \\
\text { direc- } \\
\text { tion. }\end{array}$ & $\begin{array}{l}\text { Wind } \\
\text { force- } \\
\text { Beaufort } \\
\text { Scale. }\end{array}$ & $\begin{array}{l}\text { Wind direc- } \\
\text { tion over } \\
\text { centre of } \\
\text { Bay of Bengal }\end{array}$ & Remarks \\
\hline January & WNE & $2-4$ & $\mathrm{NE}$ & $\begin{array}{l}\text { Frequent gale } \\
\text { of force } 6\end{array}$ \\
\hline Pebruary & $\mathrm{NE}, \mathrm{NNE}$ & $2-3$ & $\mathrm{NE}$ & \\
\hline March & $s, s w$ & $2-3$ & SW & $\begin{array}{l}\text { Frequent gale } \\
\text { of force } 4-\end{array}$ \\
\hline Apr 11 & S, SW & $2-3$ & SW & \\
\hline May & s, SW & $2-4$ & S, SW & $\begin{array}{l}\text { Frequent stor } \\
\text { of force } 8\end{array}$ \\
\hline June & SW & 5 & SW & $\begin{array}{l}\text { Frequent gale } \\
\text { and storms } \\
\text { force } 6-9\end{array}$ \\
\hline July & SW & $4-5$ & SW & $\begin{array}{l}\text { Frequent stol } \\
\text { of force } 9 \text { - } \\
\text { and light wil } \\
\text { of force } 2 \text { - }\end{array}$ \\
\hline August & SW & $4-5$ & SW & Same as In $\mathrm{J}$ \\
\hline September & SW & $4-5$ & $\mathrm{w}, \mathrm{SW}$ & $\begin{array}{l}\text { Frequent calr } \\
\text { and strong } \\
\text { winds of for }\end{array}$ \\
\hline October & $\begin{array}{l}\text { (NE, E } \\
\text { (above } \\
\text { (Lat. } 15^{\circ} \\
\text { ('W below } \\
\text { (SW bat. 150 }\end{array}$ & $2-3$ & $\mathrm{NE}, \mathrm{E}$ & $\begin{array}{l}\text { Erequent stol } \\
\text { of force } 8 \\
\text { wind variabl }\end{array}$ \\
\hline
\end{tabular}

$\begin{array}{llll}\text { November NE } & 2-3 & \text { NE } & \begin{array}{l}\text { Frequent stor } \\ \text { of force } 9-\end{array} \\ \text { December NE } & 2-4 & N \text { to NE } \begin{array}{l}\text { Frequent galk } \\ \text { of force } 6\end{array}\end{array}$


origin in the Western Ghats flow into the Bay of Bengal, between the hilis comprising the Eastern Ghats, traveling through the granitoid and schistose country carrying enormous quantity of sand to the sea with some of the rivers having a course of more than 800 miles through this eroding land. This partially offsets the erosive action of the sea by providing the deficiency areas with the necessary sediment moving as Iittoral drift along the coast. The major rivers contributing silt to the east coast are the Mahanadi, the Godavari, the Kistna and the Cauvery (FIg. 8). With part1cular reference to Madras the two important rivers that contribute sediment are the Pennar, north of Madras having a maximum discharge of 620,000 cfs. from a drainage area of 20,000 square miles and Cauvery in the south with a maximum discharge of 380,000 cfs. from a drainage area of 26,000 square miles. In addition, there are many other smaller rivers that contribute to the large amount of sediment along the coast (Fig. 23).

Waves - The waves that cause the littoral transport of sediment (dia. $=0.22 \mathrm{~mm}$ ) are northerly in direction from March to september and especially during the S. W. monsoon. Thoy approach the coast at about $30^{\circ}$ to the shoreline from the other direction. The surf at Madras breaks at $300^{\prime}$ from the shore in fine, at $450^{\prime}$ in squally, and at about $1000^{\prime}$ in stormy weather. In falr weather, the surf wave varies from $2^{\prime}$ to $4^{\prime}$ in height, while in rough wather it rises upto 6 ' and sometimes upto $14^{\prime}$ during gales.

The stronger $S$. W. monsoon and the more regular $S$. W. wind from March to september generate a northerly ilttoral transport during that period as compared to the southeriy creep from October to February. Thus the sediment brought down by the rivers moves up and down the coast replecing the soil eroded by the sea maintaining the shore in rough equ111brium. The effect of currents (Figs. 9, 10) on littoral transport is very small along this coast also. They aro not only reeble but act at about two miles from the shore farther away from the shallow water zone where littoral transport takes place.

Description of Harbour - As is the usual case everywhere, when the alongshore movement of sand and silt is obstructod, they tend to accumulate on one side of the obstruetion and erosion continues on the other side in an es8revated fore. This is the problem at Madras (Spring, 1912, 1919) where on artificial harbour classifled as a 'shore-lins harbour' is situated. The harbour is formed by the projection of tvo artificial breakwaters from the shorelin with the southern breakwater sheltering the harbour on the southern and eastern sides with an extension northward of the entrance known as the sheltering arm. The present entrance is situated between the outer end of the northern breakwater and the end of a short arm wich extends northwestwards from the root of the 
sheltering arm (F1g. 24).

South side Accretion - The larger northerly l1ttoral drift $\varepsilon$ a result of 1ts stoppage by the southern arm of the harbour settles on the south shoreline resulting in accretion on thy side and erosion on the north side. The effect of the weal southerly littoral drift during the North East Monsoon tryir to restore the shore back to its original profile is almost negligible. Even in the first year of 1ts construction in 1876, because of accretion, the southern shoreline had advanced 250 feet at the harbour with the accretion extending southwards for 3/4ths of a mile. By 1910, the original en. trance on the east side (F1g. 24) had to be abandoned and closed due to rapid silting and the present entrance built. the northern side. Though the rate of accretion had decreased gradually in subsequent years (Table 3) by 1912, thi accretion at the breakwater had extended seaward by $2540^{\prime}$ with a consequent southward increase to $9000^{\prime}$.

\section{Table 3 e}

\begin{tabular}{|c|c|c|c|c|c|}
\hline Perlod & $\begin{array}{l}\text { No. of } \\
\text { years } \\
\text { cons 1- } \\
\text { dered. }\end{array}$ & $\begin{array}{l}\text { Seaward } \\
\text { exten- } \\
\text { sion in } \\
\text { feet. }\end{array}$ & $\begin{array}{l}\text { Total Sea- } \\
\text { ward exten- } \\
\text { sion from } \\
\text { low water } \\
\text { I1ne of } \\
1876 \text { in } \\
\text { feet. }\end{array}$ & $\begin{array}{l}\text { Seaward } \\
\text { exten- } \\
\text { sion } \\
\text { per } \\
\text { year }\end{array}$ & $\begin{array}{r}\text { Averag } \\
\text { seawar } \\
\text { extens1 } \\
\text { per } \\
\text { year } 1 \\
\text { feet sin } \\
1876 .\end{array}$ \\
\hline $\begin{array}{l}1876-1879 \\
1879-1882 \\
1882-1898 \\
1898-1912 \\
1912-1919 \\
1919-1947\end{array}$ & $\begin{array}{r}3 \\
3 \\
16 \\
14 \\
7 \\
28\end{array}$ & $\begin{array}{r}440 \\
360 \\
1,020 \\
720 \\
230 \\
300\end{array}$ & $\begin{array}{r}440 \\
800 \\
1,820 \\
2,540 \\
2,770 \\
3,070\end{array}$ & $\begin{array}{r}147 \\
120 \\
64 \\
51 \\
33 \\
11\end{array}$ & $\begin{array}{r}147 \\
133 \\
83 \\
70 \\
64 \\
43\end{array}$ \\
\hline
\end{tabular}

Based on the amount of accretion on the south, the quantity of littoral drift was estimated to be one mililon tons per year. With such a high rate of littoral drift it was predicted at that time that in about 40 to 50 years, shoaling of considerable magnitude would start even at the new entrance unless some preventive measure were taken. Maintenance of the shoreline by continuous dredging and pur ing was found to be an impossible and a very expensive task due to the large amount of littoral drift in motion.

Remediel Megsures - It was then decided to extend seaward $t$ southern breakwater of the harbour by means of a masonry ar as 1ts south-eastern corner (F1g. 24, 25) for a distance of 720 feet so that it could serve as a sand screen and deflec the littoral drift away into deeper water areas and delay $t$ immediate extension of the shoaling process to the entrance 


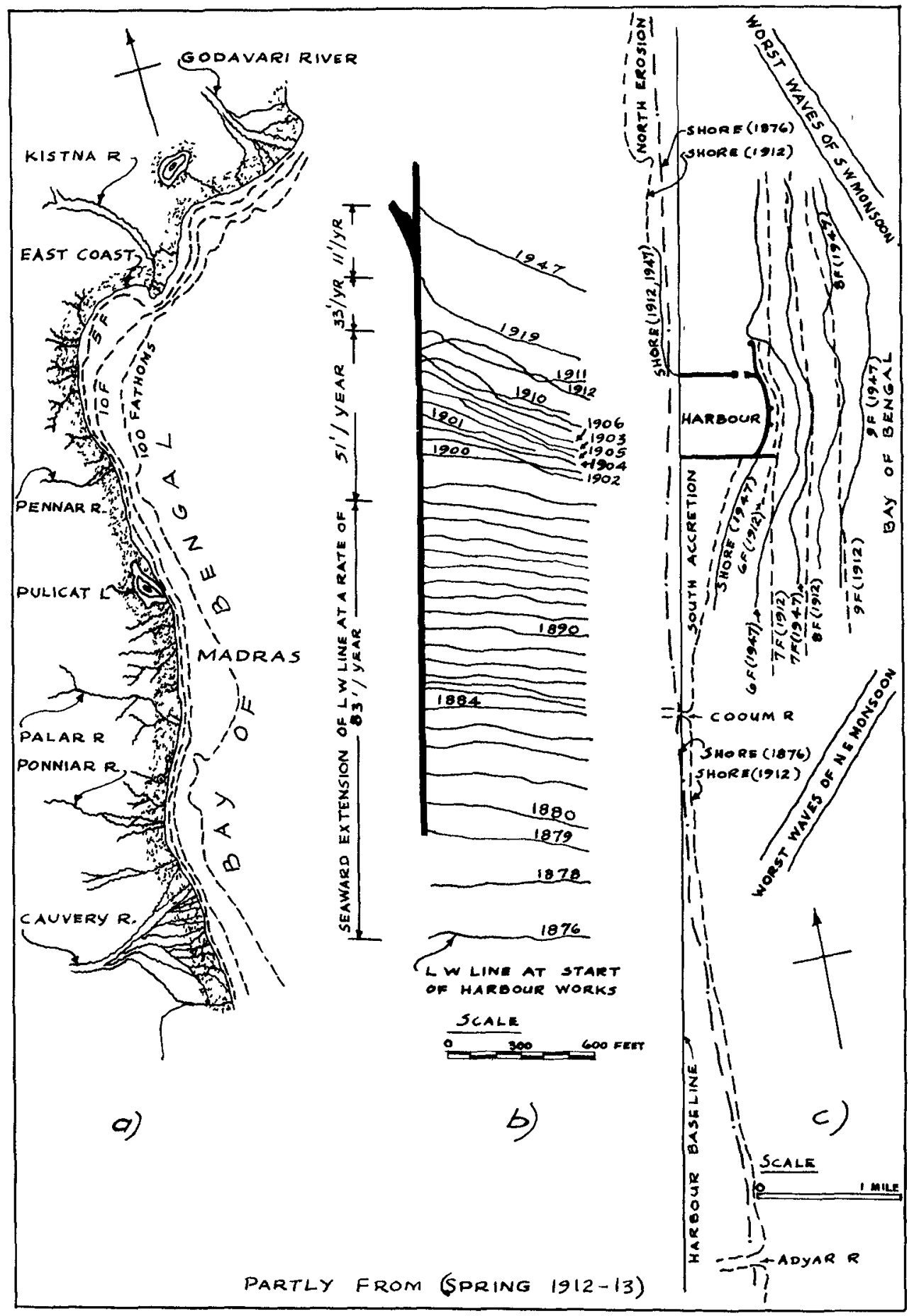

Fig. 23. Madras harbour: a) Neighbouring coast, b) Low water line at southern breakwater; c) Bottom contours in 1912 and 1947. 
channel. With the provision of the sand screen, the rate 0 seaward extension of the shoreline has considerably decrease and it has been about 11 ' per year in recent years. Since the shallow coastal shelf at Madras is narrow and ocean depths are comparatively close inshore, the sand screen seen to have served the purpose in deflecting the littoral drift to deeper areas. This, together with dredging near the sere intercepting the drift passing it has lessened to a large $\theta x$ tent the threat of sand drift closing the entrance.

cenerally the entrance has a depth of 34 ' with the area inside the harbour having a least depth of $31^{\prime}$. The rate of shallowing of the sea has also decreased considerab] since the provision of the sand screen and the commencement of the dredging operations in that locality. For example, the 6 fathom contour which was extending towards the sea at rate of $30^{\prime}$ per year before, 1s moving seaward only at a rat of $15^{\prime}$ per year since then. Figs. 23 and 24 show the appre ximate position of the contours as they existed in 1912 and 1947 .

The process of accretion and erosion when littoral movement is arrested is a manifestation by which the disturbed shoreline is trying to orlentate itself normal to the direction of the waves. In the case of Madras harbour sucl a process w1ll never be complete since it will be preceded I the extension of shoreline to the outer end of the harbour resulting in the unhindered movement of the littoral drift along the coast similar to what had existed before its construction. It is interesting to note that the or ientation of the east coast from the mouth of the river Hooghly which d1scharges into the Bay of Bengal near Calcutta upto the southern end has the upper 600 miles running roughly from north-east to south-west and the lower 400 miles from nortl to south. Along this lower stretch waves generated by botl monsoons approach the shoreline at an angle of $30^{\circ}$, a cond1. tion which has been found by model studies to result in the maximum rate of littoral drift (Savilie, 1950).

North Side Erosion - With accretion on the south side, ther was doflciency of material and the consequent erosion on th north s1de. In a per1od of 36 years an area of 450 acres land or approximately 450 mililion c. $\mathrm{ft}$. of material was -roded along this coast for a distance of $3 \mathrm{miles}$ (F1g. 23) To prevent further erosion, stone revetments were la1d on this side, which has been found to be successful to this day. The $N_{\text {. }}$. monsoon which results in a southerly movement of the i1ttoral drift at a rate of 27,000 tons per ye partiy restores the oroded portion on this side but the qua tity is so swall that its effect is negligible except as a source of trouble to the navigational entrance channel. In fuct, a small pocket of sand fills up the northside of the harbour but a month's dredging disposes it off easily. 


\section{SEDIMENT MOVEMENT AT SOUTH INDIAN PORTS}

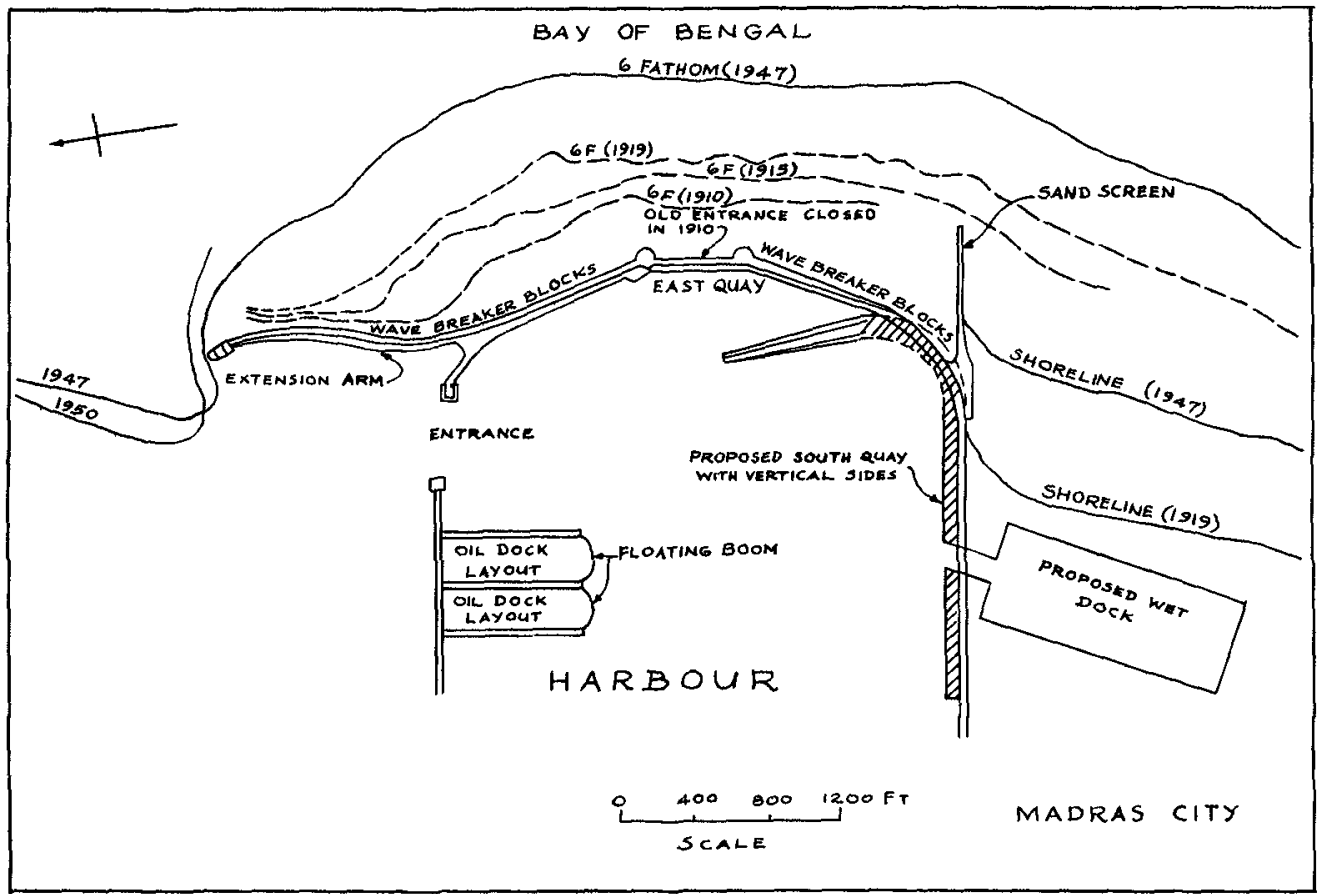

Fig. 24.-Madras harbour: Shoreline and 6 fathom contours.

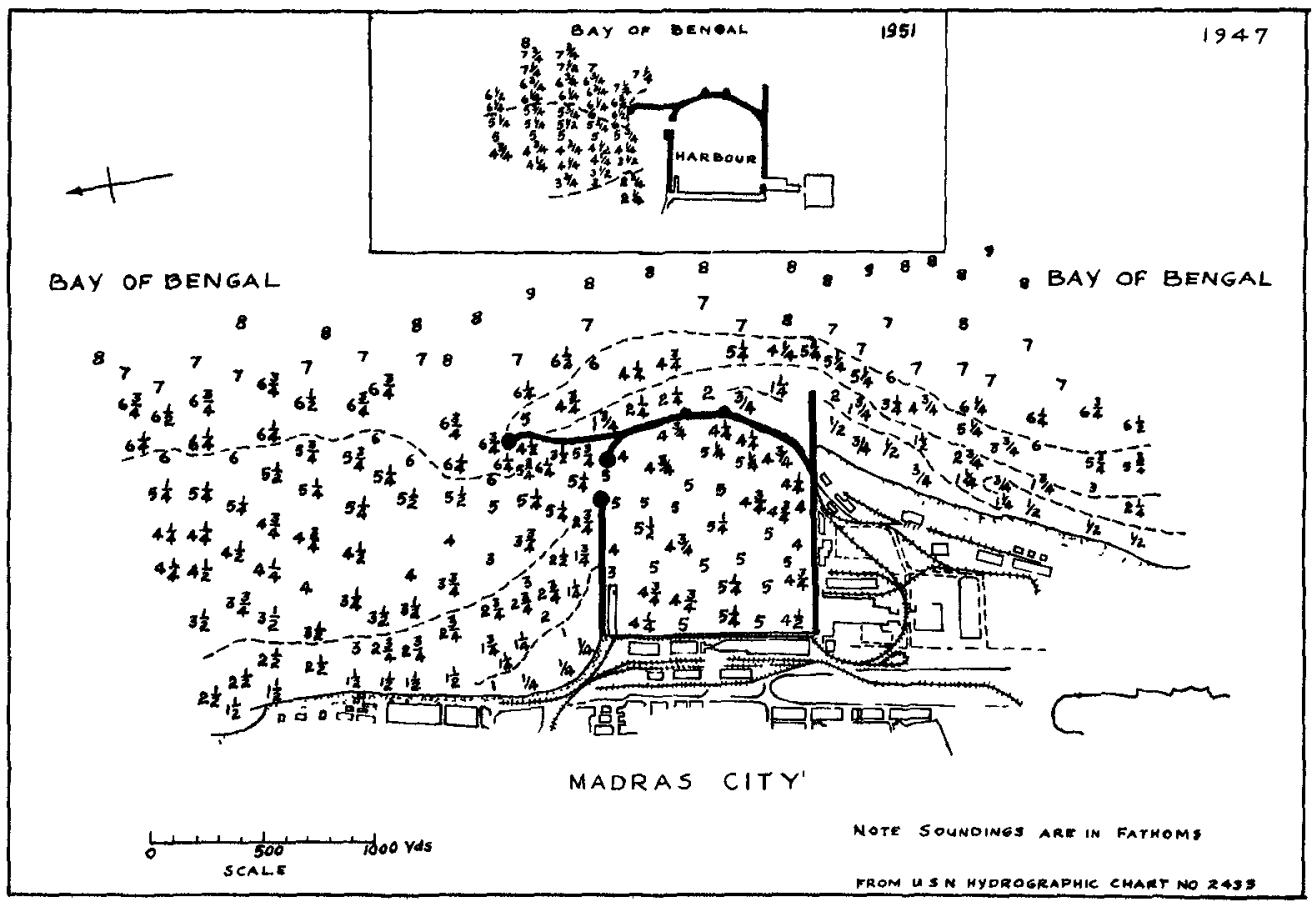

Fig. 25. Madras harbour: Bottom contours in 1947 and 1951. 
COASTAL ENGINEERING

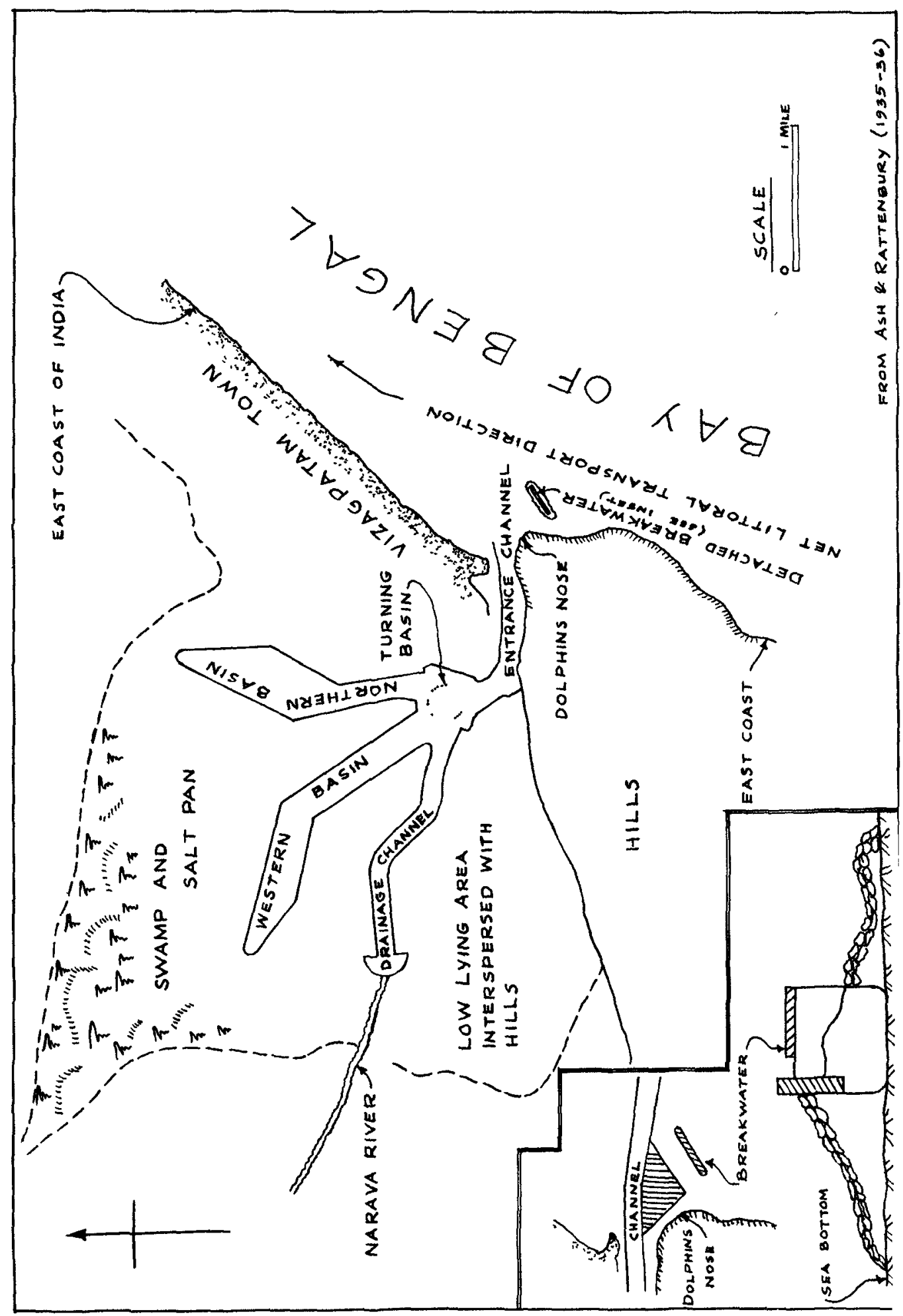

396 
Ranging - The trouble at the harbour at the present moment is not from the littoral drift but from ranging in the harbour during the N. E. monsoon from October to December, when cycIonic storms occur in the area with the consequent danger of ships within the harbour breaking their mooring ropes. The ranging is due to short period and long period waves (Central Water \& Power Research station, 1952, 1953). At the harbour, under severe conditions, they are found to be as follows:-

\section{Table 4}

\begin{tabular}{|c|c|c|c|}
\hline No. & $\begin{array}{l}\text { Wave period } \\
\text { in sea }\end{array}$ & $\begin{array}{l}\text { Wave he lght at } 1000^{\prime} \\
\text { beyond shelter area }\end{array}$ & $\begin{array}{l}\text { Wave direction } \\
\text { outside harbour }\end{array}$ \\
\hline 1 & 15.9 & 12.5 & N. E. \\
\hline 2 & 12.5 & 15.0 & N. E. \\
\hline 3 & 10.0 & 15.0 & N. E. \\
\hline 1 & 74 & 3.12 & N. E. \\
\hline 2 & 59 & 2.5 & N. E. \\
\hline
\end{tabular}

At the entrance, a range as high as $2^{\prime} 9^{\prime \prime}$ has been found to occur (Ministry of Transport, 1946). Such waves are sufficient to render every berth in the harbour untenable since those oscillations extend downward to a considerable depth. Unlike at other harbours where wave action is generally reduced inside the harbour, at Madras, the highest range reading of $3^{\prime} 6^{\prime \prime}$ occurs at the southern groyne and not at the entrance because of the fact that the harbour is bounded by four vertical walls which help to build up the range instead of decreasing the wave action.

\section{VIZAGPATAM}

Vizagpatam harbour is situated in Lat1tude $17^{\circ} 41^{\prime}$ 34', Longltude $83^{\circ} 7^{\prime} 45^{\prime \prime}$ on the east coast in the Circars coast zone. Unllke the coast at and south of Madras where there is a vast alluvial strip of 80 miles in width between the Eastern Ghats and the sea, the coast line for a considerable distance on both sides of Vizagpatam is backed by a continuous succession of rounded hills close to the sea, rocky in some places and sandy at other parts (Ash \& Rattenbury, 1935). It is a port with many natural advantages situated at the mouth of Narava river which flows into a bight and then into the sea (FIg. 26). The river has a catchment area of 200 square miles with an average rainfall of $39^{\prime \prime}$. Sometimes severe floods are encountered in this area during the 


\section{COASTAL ENGINEERING}

months from Dctober to December when a rainfall of 24 " may b registered in 3 days and sometimes 12" in one day. During such floods enormous quantity of silt is brought by the rive into the bight and in fact it was a large swamp before its 1mprovement as a harbour. On the south side, it is protect ed by a rocky h1ll which ends in a bluff headland $4300^{\prime}$ sout wards, rising 536' high near the sea. This headland is kno as Dolphin's Nose from 1ts profile. On the north side, it is protected by a sandy spit on which the town of vizagpatam with its numerous hilis, is situated. Most probably the bight was once part of the sea, the sandy spit having been formed at a later stage due to littoral and silting effects in the region. Between the Dolphin's Nose and the sandy spit, a short entrance channel is provided in the gut throug which the river water is discharged into the sea. The coas ine in the vicinity of the entrance channel has a northeasterly direction in the northern sandy spit while immediately south of the entrance where the coast is rocky, it takes a sudden bend in the northwesterly direction. This harbour may be classified as a "fall-1ine harbour". As is the case in almost all cases where a river discharges into the sea, a sand bar across the river outlet used to exist be fore the entrance channel was dug. The bar at the time of its existence changed its position depending upon the seasor and the year and had a depth as low as $2^{\prime}$ below low water level.

Waves and Littoral Drift - The waves approach the harbour ir a direction of about $50^{\circ}$ south of east from the end of February to the end of September. During the $S$. W. monsoon season from May to September, the waves approach the coastilne, south of Vizagpatam from a southerly direction result. ing in a northward littoral drift. During the roughest pe. riod of this season waves of $25^{\prime}$ to $30^{\prime}$ in helght at depths of $25^{\circ}$ to $30^{\prime}$ may occur and last for 8 to 10 days resulting In northerly drift as high as 200,000 tons. During such b: weather, wind is 11 ght indicating that the huge waves are di to some disturbance far away. In October, conditions are variable but by the end of that month, the wave direction changes by about $50^{\circ}$ and the waves approach practically duo east. This being the N. E. monsoon period, cyclones are of lesser intensity and since the waves approach the shore witl a southern obliquity, there results a southerly drift of se. diment of lesser magnitude. In February and October when frequent calms occur, the ilttoral drift is small.

T1des and Currents - The t1dal range varies from $7 "$ in the neaps to $5^{\prime} 9^{\prime \prime}$ in the springs. The tidal currents in tho harbour are small though they may attain a velocity of $1 \mathrm{kn}$ in the gut. The onshore currents set up by the winds folli generaliy the same direction as the littoral drift movement but are too feeble to affect the movement of littoral drift which mainly consists of coarse sand and very little of fine sand. 


\section{LITTORAL DRIFT AND REMEDIAL MEASURES}

The problem at the harbour 1s, therefore, the effect of littoral drift moving up and down the coast on the entrance channel and the coast 11 ne. Just as at Madras, the S. W. monsoon being stronger, the northerly littoral drift is larger in magnitude of the order of 1 million tons per year, a fairly constant quantity that moves up and down along the east coast. At vizagpatam, the southerly transport amounts to only 200,000 to 300,000 tons - a small quantity that is distributed over a wide area. To keep the entrance channel from getting silted up from the enormous northerly littoral drift either continuous dredging or protective breakwater or both are essential. Maintenance by dredging alone would, not only be impossible and too expensive but also hazardous due to the ordinary swells of $5^{\prime}$ to $1^{\prime}$ ' and large waves of $25^{\prime}$ to $30^{\prime}$ that occur during the $\mathrm{s}$. W. monsoon. The situation is entirely different from that at cochin on the west coast where the littoral drift is very small and where the obb tide with its great flushing effect disposes of a large quantity of silt. Therefore, it is necessary to trap the ilttoral drift before it reaches the channel and the harbour and dispose it off to the northside to prevent erosion on that side.

At the time of harbour construction, two alternatives wre possible, namely (1) a continuous breakwater from near. Dolphin's Nose extending seaward for a long distance and (2) a detached breakwater serving the same purpose, a short distance away from the shore. As at Madras, a continuous breakwater from Dolphin's Nose would have caused considerable siltation on its southern side in a very short time necessitating continuous dredging on the weather side in order to keep the accretion from creeping around the breakwater and then into the channel. At Madras, there was no other cholce, since the main harbour itself is situated within the breakwaters while at vizagpatam, the harbour is situated inward from the sea in a bight. Also at Madras, low lying sandy beach and deep water areas were very near the shore on the southern side - conditions that were suitable for the construction of a shore connected breakwater with its extension arm. At Vizagpatam that was not possible in the immediate vicinity of the harbour due to the steep rocky face of the Dolphin's Nose. Southwards of Dolphin's Nose, the sea bed consisting of clean sand had a slope of 1 in 100 and majority of the littoral movement was observed to take place in localitles where the waves exceeded $6^{\prime}$ in helght. These were found to be at a short distance away from the shore within a $600^{\prime}$ zone in the shallow water areas.

Detached Breakwater - From all these considerations, a detached breakwater on the south side of the channel sufficiently far away from the shore to ensure a comparatively sheltered area and aligned in such a way that sand could be made 
to pass between it and the Dolphin's Nose and allowed to settle in the sheltered area in its lee, was constructed (Pig. 26). By so doing, it became possible for a dredger $t$ work safely in the sheltered area and transport the trapped ilttoral material by means of a pipeline to the under-nourished sand spit and adjacent areas on the northside. The breakwater was constructed by sinking two tramp ships stern to stern with their bows forming the two ends of the breakwater. They were sited in comparatively shallow water of depths varying from $18^{\prime}$ to $25^{\prime}$ below low water. The ships settled only $3^{\prime}$ on the sea botton composed of clear coarse sand. To protect the breakwater from wave action, a rock fill was placed around the ships and in the small space provided between the ships (F1g. 26). The breakwater which wa approximately 1000 ' long ldeally fulfilled its purpose by causing the ilttoral drift to deposit in the lee of the breakwater from where it was disposed off to the north side. only $3 \%$ of the total drift passes around the outer end of th breakwater. There has been some shoaling between the Dolphin's Nose and the breakwater since its construction.

By dredging the $300^{\circ}$ channel and the sand trap, it ha been found possible to keep the harbour in operation at all times without any difficulty. Cenerally a depth of $33^{\prime}$ is maintained in the entrance channel. The harbour consists o an extensive besin eminently fitted for a large harbour and is being expanded to become one of the finest harbours in India.

\section{SUMMARY}

Littoral transport which is mainly due to the action of waves depends on rivers, sea bottom, and shore line for its sediment supply. The direction of littoral drift depends mainly upon the configuration of the coastilne, the direction of the wind system and the waves. The rate of ilttoral transport may be obtained by methods similar to Einstein's theory of sediment transport in uni-directional flow in addition to the standard field methods. When oquilibrium of movement of littoral drift is disturbed as in the case of harbours where protective breakwaters, groynes, nav1 gational channels and other similar facilities are provided excessive accretion and erosion take place in the neighbouring zones. To reduce and stop erosion and accretion, preventive measures have to be taken, and they depend upon the amount and direction of littoral drift and the type, locat 10 and size of the harbour.

The outstanding feature of the wind system in the Indian Ocean is the seasonal reversal of its wind direction known as the monsoon. During the $S$. W. monsoon from June $t$ September and sometimes earlier in some reglons, the wind an the waves approach the east and west coasts of $S$. India from the s. W. direction creating a northerly littoral drift. Frc 
December to March, when the N. F. monsoon prevalls, the wind and the waves approach the east coast from a N.E. direction and the west coast from a $N$. W. direction creating a southerly littoral drift. The stronger $s$. W. monsoon results in a net northerly littoral drift. Because of the fact that most of the rivers originate from the Western Ghats on the west coast and flow into the Bay of Bengal on the east traversing through alluvial country, a large amount of sediment discharged by these rivers into the sea moves up and down the east coast resulting in a net northerly littoral drift of 1 mililion tons per year. on the contrary very few rivers flow into the Arabian sea on the west coast so that the net northerly littoral drift is small of the order of 42,000 tons to 200,000 tons per year with the greater quantity in motion near river outlets.

Cochin harbour on the west coast is formed in a large backwater between the mainland and two narrow peninsulas and may be classified as a channel harbour in tidal estuary. Since the littoral drift is small, erosion and accretion along the adjacent coasts are not great. A large quantity of silt and mud brought into the backwater during the monsoons from the Western Ghats are discharged into the sea by the large ebb tide from the backwater thereby resulting in less siltation in the harbour and adjacent areas. The only protective works found necessary are the groynes and bunds on the shorelines-north and south of the channel. The entrance channel and the harbour are maintained by dredging for a few months. Along the west coast within short distances from Cochin there exist mudbanks similar to those found alorg the Mississippl river delta. They appear suddenly in different places, are not permanent and are generally moved by the stronger southerly currents.

Mangalore port situated on the west coast further north of Cochin may also be classified as a channel harbour in t1dal estuary. Unlike Cochin harbour where the backwater forms the tidal estuary, at Mangalore, it is formed at the junction of two rivers and the sea. The littoral drift is about 200,000 tons per year while river deposits are still greater with the result that maintenance by dredging and protective works is impracticable. At present it is only an open roadstead.

Madras harbour on the east coast is a shore-1ine harbour constructed by the seaward extension of breakwaters from the shore. With the littoral drift at one miliion tons per year, accretion on the south side is so enormous, that the old entrance on the east side closed 34 years after its construction in 1876 is, at present, replaced by a new entrance on the northside behind a long sheltering arm. A masonry extension at the south eastern end of the harbour extending seaward to deeper areas and serving as a sand screen together with dredging in that locality has been found to reduce the 
rate of advance of accretion on the south side. The rate o advance of accretion is about $11 \mathrm{ft}$. per year, at present, a compared to $250 \mathrm{ft}$. per year at the time of construction of the harbour. Shoaling of entrance by accretion is no longe a threat to the harbour.

Vizagpatam situated on the east coast, north of Madra is formed in a bight fed by a small river and separated from the sea by a rock outcrop and a sandy spit and may be termed a fall-line harbour. A northerly littoral drift of 1 mililon tons per year exists along this coastal strip as at Madras. To keep the navigational channel from silting, a d tached breakwater about 1000 feet long in the form of two sunken ships is provided on the south side of the channel, a short distance from the shore trapping the littoral drift passing through the gap and causing settlement in 1ts lee. Dredging of the trapped ilttoral drift from this calm area and its disposal by pipe line to the undernourished north si have been found to be the most effective arrangements at thi harbour.

\section{REFERENCES}

Ash, W. C. and Rattenbury C. B. (1935-36) "V1zagpatam Harbour" Min. Proc. of Inst. of Civil Engineers, London, Vol. 1. Bristow, R. C., (1930) "Cochin Harbour Works", Min Proc. of
Inst. of Civil Engineers, London.

Bristow, R. C., (1938). "The History of Malabar Mud Bank", Vol. I, Cochin Port Authorities (not for circulation)

Brlstow, R.C., (1938). "The H1story of Malabar Mud Bank", vol. II, Cochin Port Authorities (not for circulation

Caldwell, J.M., (1950). "Sedimentation in Harbours" Applled Sedimentation, Bd. P. D. Trask, John Wiley \& Sons. pp 291-99.

Caldwell J. M., (1956). "Wave Action and Sand Movement Near Anheim Bay, California, Tech. Memo No, 68, Beach Erosion Board, Corps. of Ingineers, Washington D.C., 21 pp.

Central Water and Power Research Station, (1952). "Annual Report (Technical)", Ministry of Irrigation and Power Government of India, Poona.

Central Water and Power Research Station, (1953). "Annual Report (Technical)", Ministry of Irrigation and Power, Government of India, Poona. 
Central Water and Power Research Station, (1954). "Annual Report (Technical)", Ministry of Irrigation and Power, Government of India, Poona.

Da1ly J. W., Stephen S. C., (1951). "Character1st1cs of Solitary Waves" Proc. Am. Soc. of Civil Engineers, Vol. 77, Separate 107.

Dunham, J.W., (1950). "Refraction and Diffraction Diagrams", Proc. First Conf. of Coastal Fingineering pp. 33-49.

Eaton R.0., (1950). "Littoral Processes on Sandy Coasts" Proc. First Conf. of Coastal Englneering pp. 140-54.

Einstein, H.A., (1950). "Bed-load Function for Sediment Transportation in Open Channel Flows", Tech. Bul.1926, U. S. Dept. Agriculture, Soll Conservation Service.

Einstein, H. A., (1942). "Formulas for Transportation of Bed Load, "Trans. Am. Soc. of Civil Engineers, Vol.107, pp. 561-73.

Gilbert, G. K., (1890). "Lake Bonneville" Monographs of U. S. Céological Survey, Vol. I, 584 pp.

Hydrographic Dept., (1953). "Bay of Bengal P1lot" 8th Ed1tion, Admiralty, London.

India Meteorological Dept., (1941). "Winds, Weather, and currents on the coast of India and the Laws of Storms", and Bdition, Poona.

Inman D. L. and Quinn W.H., (1951). "Currents in Surf Zone" Proc. Second Conf. on Coastal Engineering, pp. 130-44.

Johnson, D. K., (1919). "Shore Processes and Shoreline Dem velopment", John Wiley \& Sons, 584 pp.

Johnson J. W., (1953). "Sand Transport by Iittoral Curm rent s", Proc. Fifth Hydr. Conf. Bul. 34, State Univ. of Iowa Studies in Eng ., pp. 89-109.

Johnson, J.W., (1957). "The Iittoral Drift Problem at Shoreline Harbours", Proc. Am. Soc. of C1vil Engineers, Vol. 83 , No. WW I pp. 12II-1 to 37 .

Johnson, J. W., (1956). "Dynamics of Nearshore Sediment Movement" Bul. of Am. Assoc. of Petroleum Geolog1sts, Vol. 40, No. 9, pp. 2211-32.

Johnson, J.W., (1953). "Eng Ineering Aspects of Diffraction and Refraction", Trans. Am. Soc. of Civil Engineers, Vol. 118, pp. 617-52. 
Johnson J. W., (1951). "Ceneralised Wave Diffraction Diag" rams", Proc. Second Conf. on Coastal Englneering, pp. 6ine3.

Kuenen Ph. H., (1950). "Marine Geology" John W1ley \& Sons, pp. 221-32 and 251-76.

Manohar M., (1955). "Mechanics of Bottom Sediment Movement due to Wave Action" Tech. Memo 75, Beach Erosion Board, Corps of Engineers, Washington D. C., $121 \mathrm{pp}$.

Mason, M. A., (1950). "Geology in Shore Control Problems" Applied Sedimentation, Jokn Wiley \& Sons. pp. 276-90.

Meteorological office, (1940). "Weather in the Indian Ocean, West Coast of India from Lat. $20^{\circ} \mathrm{N}$ to Cape Comorin", Vol. II, part 5, Air Ministry, London.

Meteorological office, (1940). "Weather in the Indian Ocean, East Coast of Indla from Cape Comorin to the Ganges Delta and Ceylon", Vol. II, part $6 \mathrm{~A}$ and $6 \mathrm{~B}$, Air Ministry, London.

Ministry of Transport, (1946) "Report of Ports (Technical) Committee (1946)" Government of India.

Ministry of Transport, (1950). "West Coast Major Port Deve lopment Committee Report and Recommendations Regardi1 the Possibility of siting a Major Port on the coast Between Mormugao and Cochin", Government of Ind1a.

Morgan J.P., (1951). "Mudlumps at the Mouths of the Miss1. ssipp 1 River" Proc. Second Conference on Coastal Eng: neering. pp. 130-44.

Munk, W.H., (1949). "The Solltary Wave Theory and 1 ts Appilcation to Surf. Problems "Annals of the New Yorl Academy of Sclence, Vol. 51, pp. 396-401.

Sav1lle T. Jr., (1950). "Model Study of Sand Transport Along an Infinitely long Straight Beach", Trans. Am. Geophy Union, Vol. 31, pp. 555-65.

Shepard F. P. and Inman D. I., (1950). "Nearshore Circula. tion" Proc. First Conf" on Coastal Engineering, pp. 350-59.

Tsubak1, T., Kawasum1, T., Yasutom1, T., (1953). "On the Influence of Sand Ripples upon Sediment Transport in Open Channels" Vol. 2. Research Inst. for Applied Mechanics, Kyushu Univ. Japan, pp. 242-56. 
Spring F. J. E., (1912-13). "Coastal Sand Travel near Madras Harbour" Min. Proc. Inst. of Civil Engineers, London, Vol. 194, pp. 153-71.

Spring F.J.E., (1919m20). "Coastal Sand Travel near Madras Harbour" Min. Proc. Inst. of Civil Engineers, London, Vol. 210, pp. 27-28.

U. S. Army, (1954). "Shore Protection - Planning and Design" Tech. Rept. 4, Beach Erosion Board, Corps of Bngineers, pp. 67-76.

Watts G. M., (1953). "A Study of Sand Movement at South Lake Worth Inlet, Florida" Tech. Memo 42, Beach Erosion Board, Corps, of Englneers, Washingt on D. C., pp. 23. 